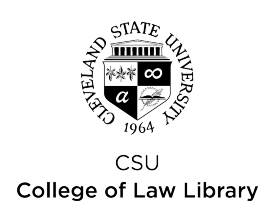

Cleveland State University

College of Law Library

\title{
EngagedScholarship@CSU
}

\section{The Demise of Regulation in Ocean Shipping: A Study in the Evolution of Competition Policy and the Predictive Power of Microeconomics}

Christopher L. Sagers

Cleveland State University, c.sagers@csuohio.edu

Follow this and additional works at: https://engagedscholarship.csuohio.edu/fac_articles

Part of the Antitrust and Trade Regulation Commons

How does access to this work benefit you? Let us know!

\section{Original Citation}

Christopher Sagers, The Demise of Regulation in Ocean Shipping: A Study in the Evolution of Competition Policy and the Predictive Power of Microeconomics, 39 Vanderbilt Journal of Transnational Law 779 (2006)

This Article is brought to you for free and open access by the Faculty Scholarship at EngagedScholarship@CSU. It has been accepted for inclusion in Law Faculty Articles and Essays by an authorized administrator of EngagedScholarship@CSU. For more information, please contact research.services@law.csuohio.edu. 


\section{HEINONLINE}

Citation: 39 Vand. J. Transnat'I L. 7792006

Content downloaded/printed from

HeinOnline (http://heinonline.org)

Tue May 22 10:01:34 2012

-- Your use of this HeinOnline PDF indicates your acceptance of HeinOnline's Terms and Conditions of the license agreement available at http://heinonline.org/HOL/License

-- The search text of this PDF is generated from uncorrected OCR text.

-- To obtain permission to use this article beyond the scope of your HeinOnline license, please use:

https://www.copyright.com/ccc/basicSearch.do?

\&operation $=$ go\&search Type $=0$

\&lastSearch $=$ simple\&all=on\&titleOrStdNo=0090-2594 


\title{
The Demise of Regulation in Ocean Shipping: A Study in the Evolution of Competition Policy and the Predictive Power of Microeconomics
}

\author{
Chris Sagers $^{*}$
}

\begin{abstract}
Over its 140 year history, ocean liner shipping has almost always enjoyed an antitrust exemption permitting price-fixing cartels of ocean carriers. The exemption was premised on the belief that problems of cost and capacity inherent in the trade can be resolved only by horizontal collusion. Now that that exemption has been whittled away by deregulatory efforts, the pre-and post-deregulation evidence presents one of the world's rare opportunities for natural experiment on the behavior and effectiveness of collusive cartel pricing.

Moreover, because normal and effective competition never really existed prior to 1998 , the normative foundation of the antitrust exemption was based almost entirely on theoretically modeled economic arguments. Observing the industry's behavior under deregulation is therefore a before-and-after opportunity to test the predictive accuracy of at least one body of economic argument. Finally, the evolution of shipping policy is also part of a larger historiography-the shipping exemption reflects the larger story of government efforts to cope with the problems of industrial organization.
\end{abstract}

\footnotetext{
* Assistant Professor of Law, Cleveland State University; I welcome all feedback at csagers@law.csuohio.edu. My thanks for feedback to Peter Carstensen and Spencer Weber Waller. Steve Calkins provided substantial comments on a slightly different version.

This Article builds on formal comments drafted by the Author on behalf of the Section of Antitrust Law, American Bar Association, for submission by the Section to the U.S. Antitrust Modernization Commission, an ad hoc expert body empanelled by Congress in 2002. The Section's official comments are available at $\mathrm{http}: / / \mathrm{www}$.amc.gov/ public_studies_fr28902/immunities_exemptions_pdf/060317_ABA_Shipping_Act.pdf.
} 


\section{TABLE OF CONTENTS}

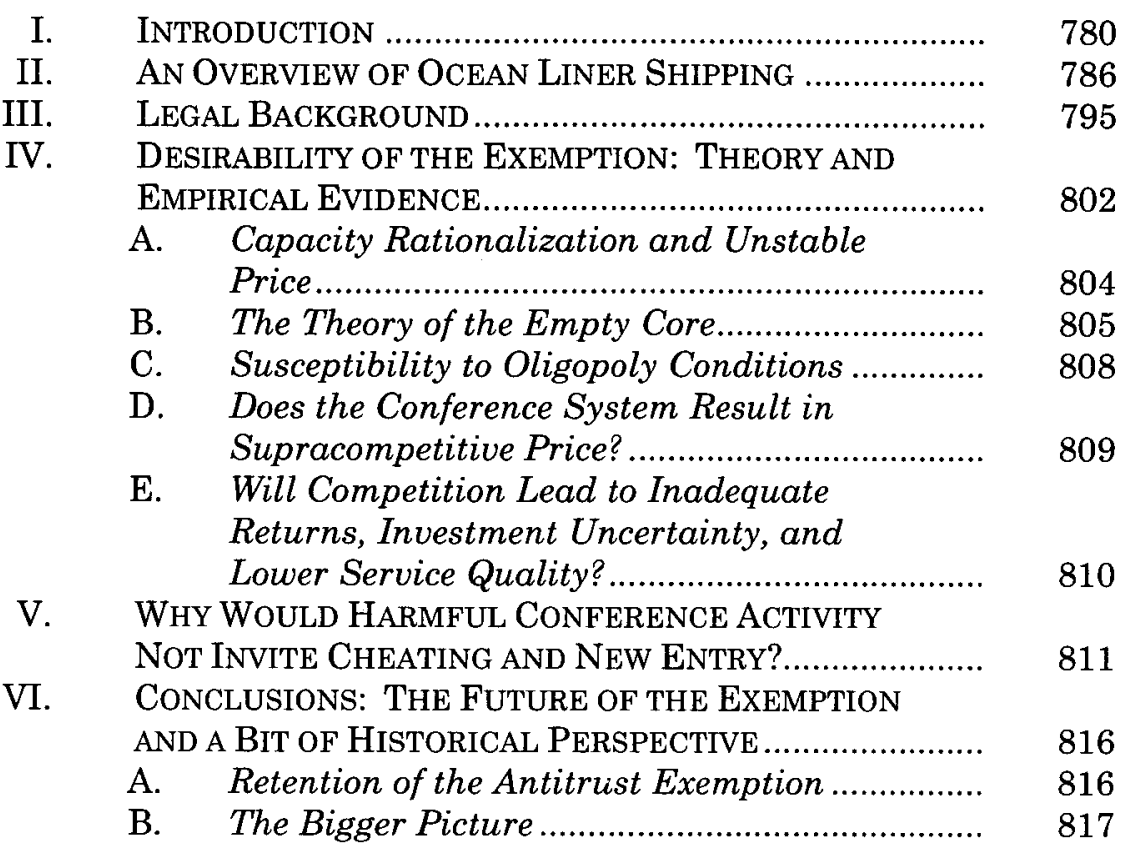

\section{INTRODUCTION}

Among the world's most active reform movements in international trade and business regulation is the effort to deregulate ocean shipping fully. During its 140 year history, the shipping industry has almost always been shielded, everywhere in the world, from competition law and open competition. ${ }^{1}$ Accordingly, until quite recently most pricing and output decisions were made by horizontal cartel. ${ }^{2}$ Like all other transportation sectors, however, the industry has faced increasing efforts to remove its regulatory protections and subject it to open competition. Indeed, the industry was partially deregulated under U.S. law by legislation that took effect in $1999 .{ }^{3}$ More recently, there have been unsuccessful attempts to do away

1. See infra notes 66-67 and accompanying text.

2. H.R. Tosdal, Open Price Associations, 7 AM. ECON. Rev. 331 (1917).

3. Ocean Shipping Reform Act of 1998, Pub. L. 105-258, 112 Stat. 1902 (1998), amending various provisions of the Shipping Act of 1984, 46 U.S.C. app. $\S \S 1701-19$ (1984 Act). 
with the U.S. antitrust exemption entirely, ${ }^{4}$ and though the effort has not yet reached floor consideration in Congress, it has had significant support. ${ }^{5}$ The European Commission is poised to do the same with its ocean shipping exemption within the next year or so, ${ }^{6}$ and similar reform proceedings recently have taken place in Australia, Canada, Japan, and South Korea. ${ }^{7}$ Other influential critiques of ocean

4. Free Market Antitrust Immunity Reform Act (Fair Act) H.R. REP. No. 3138 (1999) (first introduced), H.R. REP. No. 1253, 107th Cong. 2001(reintroduced). The Fair Act would phase out the U.S. antitrust exemption as to all ocean shipping agreements except those among marine terminal operators. See H.R. REP. No. 1253 (2001); H.R. REP. NO. 3138 (2000).

Indeed, even OSRA and the 1984 Act were compromise measures between carriers and a variety of parties that sought to eliminate the antitrust exemption altogether. See Donald T. Bliss \& David T. Beddow, Should the Shipping Act of 1984 Be Amended to Eliminate Conference Antitrust Immunity?, 36 FED. B. NEWS \& J. 357, 357-60 (1989); Constantine G. Papavizas \& Lawrence I. Kiern, 1997-1998 U.S. Maritime Legislative Developments, 30 J. MAR. L. \& CoM. 487, 488-89 (1999).

5. The Fair Act bill has had the support of two House Judiciary Chairmen and the Antitrust Division under the administrations of both Presidents Clinton and George W. Bush. The bill was introduced in the 106th Congress by then-Chairman Hyde and in the 107th by present-Chairman Sensenbrenner. As for the current views of the Antitrust Division, see Free Market Antitrust Act of 2001: Hearing Before the House Committee on the Judiciary on H.R. 1253, 107th Cong. (statement of Charles James, Assistant Attorney General, U.S. Dept. of Justice, Antitrust Division); Free Market Antitrust Act of 1999: Hearing Before the House Committee on the Judiciary on H.R. 3138, 106th Cong. (statement of John Nannes, Deputy Assistant Attorney General, U.S. Dept. of Justice, Antitrust Division).

As it happens, opinions concerning the Shipping Act exemption has varied over time. Compare U.S. DEPT. OF JuSTICE, The REgulated OCEAN ShIPPING INDUSTRY (1977) (critical of the exemption) with Comptroller Gen., Gen. Accounting Office, Changes in Federal Maritime Regulation Can Increase Efficiency and Reduce Costs in the Ocean Liner Shipping Industry, REPORT TO THE CHAIRMAN, H. COMM. ON MERCH. MARINE \& FISHERIES at App. I (1982) [hereinafter GAO REPORT] (reprinting, as an Appendix, a Justice Department letter urging expansion of the Shipping Act exemption to permit "greater freedom to engage in restrictive business practices.").

6. See Proposal for a Council Regulation Repealing Regulation (EEC) No. 4056/86, 2005/0264 (CNS) (Dec. 14, 2005) [hereinafter EC Proposal] (proposing regulation to repeal EU shipping exemption); Commission White Paper on the Review of Regulation 4056/86, Applying the EC Competition Rules to Maritime Transport, Comm. Prog. 2003/COMP/18, (Oct. 13, 2004) [hereinafter EC White Paper]. The EC's proposed repeal awaits action by the European Council.

7. Australia's government has referred the matter to the Australian Productivity Commission, an independent government agency charged with reviewing the economic effects of government policy, and the Commission reported in 2005 that its "strongly preferred option is to repeal" the ocean liner shipping exemption under Australian competition law. Australian Government, Productivity Commission, Review of Part X of the Trade Practices Act of 1974: International Liner Cargo Shipping XL (2005). Canada has modified its exemption to introduce greater competition, and it has indicated that for reasons of comity and the competitiveness of the Canadian industry it will generally follow the U.S. deregulatory lead. See Transport Canada, Transportation in Canada 2000, 2-3, available at www.tc.gc.ca/pol/en/anre2000/ tc0011ee.htm. Japan and South Korea retain some immunity but have performed similar reviews in recent years. 
shipping exemptions also have emerged, notably from the Organization for Economic Cooperation and Development (OECD) and from economists at the World Bank. ${ }^{8}$ Deregulatory reforms are among the key issues before the U.S. Antitrust Modernization Commission, a congressionally appointed panel of experts currently studying the antitrust laws. ${ }^{9}$

And yet the privileged status of this particular industry not only lingers, it is fiercely defended. This is in part because "deregulation" is still a relatively young phenomenon in which even impartial observers express some doubts, ${ }^{10}$ and there remains enough uncertainty that traditionally regulated firms can claim they still need an exemption from antitrust laws. ${ }^{11}$ But a devoted core of

8. Org. for Econ. Cooperation and Dev., Dir. for Sci., Tech. and Industry, Competition Policy in Liner Shipping, FINAL REPORT (2002) [hereinafter OECD FINAL REPORT]; Carsten Fink et al., Trade in International Maritime Services: How Much Does Policy Matter? (World Bank Dev. Research Group, Working Paper No. 2522, 2001).

9. The AMC has on its docket reconsideration of a range of antitrust issues concerning regulated industries, and it has taken them on as a major component of its work. In addition to reconsidering the shipping exemption, the AMC will address: (1) the surprisingly long list of other industry-specific exemptions from antitrust, most of which are statutory, but some of which are not, including the notorious caselaw baseball exemption; (2) general questions about the appropriate balance of competition policy oversight in regulated industries; and (3) the Supreme Court's recent Trinko decision, in which the Court seemed to inaugurate a new sort of judicial deference in the application of antitrust laws to regulated industries, even where the statutory regulatory regime contains a broad antitrust savings clause. See Memorandum from Andrew J. Heimert, Reg. Indus. Working Group to Antitrust Modernization Comm. re Regulated Indus. Issues Recommended for Comm. Study (Dec. 21, 2004), available at www.amc.gov (discussing issues recommended for AMC study).

The AMC will submit a report to the President and Congress in mid-2007 recommending legislative or administrative changes to antitrust regulations. See generally Chris Sagers, A Critical Introduction to the Antitrust Modernization Act, 3 ZEITSCHRIFT FÜR WETTBEWERBSRECHT (forthcoming 2006).

10. Many observers seem to think that deregulation is a good idea in theory but that it is too early to say for sure whether it has been a net positive. See generally Christopher Clott \& Gary S. Wilson, Ocean Shipping Deregulation and Maritime Ports: Lessons Learned from Airline Deregulation, 26 TRANSP. L.J. 205, 207-09 (1998) (discussing debate among economists and policy advocates of deregulation in various transport industries); Alfred E. Kahn, Airline Deregulation-A Mixed Bag, But a Clear Success Nevertheless, 16 TRANSP. L.J. 229 (1998) (detailing economic evidence concerning performance of airlines following deregulation). Even strong proponents of open competition have criticized deregulatory efforts so far, often because deregulation in many industries remains incomplete. See, e.g., Peter C. Carstensen, Evaluating Deregulation of Commercial Air Travel: False Dichotomization, Untenable Theories, and Unimplemented Premises, 46 WASH. \& LEE L. REV. 109 (1989); Kahn, supra; cf. Alfred E. Kahn, Deregulatory Schizophrenia, 75 CAL. L. REV. 1059 (1987) (arguing that deregulation on its own is vulnerable to industry abuse and requires healthy antitrust enforcement).

11. As has been the case in other regulated industries, particularly at times of proposed deregulation, the liner carriers have defended their special legal status on the basis of economic dysfunctions allegedly inherent in their trade. In fact, in the developed world, ocean shipping is among the last of the traditionally regulated 
advocates continues to believe that ocean shipping is in some way special and poorly suited for open competition. Interestingly, a small collection of academics remains convinced that ocean shipping is a real-world case of a special, rarely tested theoretical problem described as the problem of the "empty core." 12

This moment of world attention is therefore an opportune one for consideration of a number of important issues of policy and economic theory. Again, the industry was partially deregulated in $1999 .^{13}$ The pre- and post-deregulation evidence now available presents one of the world's rare opportunities for natural experiment on the behavior and effectiveness of collusive cartel pricing (rare because price-fixing is normally illegal and therefore done in secret). Likewise, because normal and effective competition never existed prior to 1999 , the normative foundation of the antitrust exemption was based almost entirely on theoretically modeled economic arguments. Observing the industry's behavior under deregulation is therefore a before-and-after opportunity to test the predictive accuracy of a body of economic argument, including the "empty core" theory. Finally, shipping deregulation tells a larger historiographical story of an evolution in U.S. competition policy.

This Article sets forth two major themes. First, deregulatory experience suggests that ocean liner markets can perform well under normal price competition, contrary to long-standing claims from the industry and some academics. The carriers themselves have long argued that peculiar cost and capacity problems of their trade would render performance under competition impossible. Prior to deregulation, a body of theoretical work grew to support the carriers' claims, bolstering the argument that they required antitrust immunity. ${ }^{14}$ Some empirical support developed as well. ${ }^{15}$ Criticism

industries to face deregulation, and the industry appears to be following a now familiar pattern. See OECD FINAL REPORT, supra note 8, at 54, 68 (discussing capital-intensive industries (e.g., the power-generating sector, telecommunications, rail and air cargo transport) that previously argued that they should retain the same antitrust immunity for price-fixing currently afforded to the liner-shipping sector).

12. The theory of the empty core is a more sophisticated modern variant of the destructive competition argument by which the shipping exemption was traditionally defended. The theory was originated by economist Lester Telser of the University of Chicago and is now associated with a loosely affiliated group of economists, several of whom were Telser's doctoral advisees. See infra notes 119-26 and accompanying text.

13. See Ocean Shipping Reform Act of 1998, supra note 3.

14. See Stephen C. Pirrong, An Application of Core Theory to the Analysis of Ocean Shipping Markets, 35 J.L. \& Econ. 89 (1992); William Sjostrom, Antitrust Immunity for Shipping Conferences: An Empty Core Approach, ANTITRUST BuLL., Summer 1993, at 419; see also William Sjostrom, Liner Shipping: Modeling Competition and Collusion, in HANDBOOK OF MARITIME ECONOMICS AND BUSINESS 307 (Costas T. Grammenos ed. 2002) [hereinafter Sjostrom, Modeling Competition]. 
also predated deregulation, ${ }^{16}$ however, and grew after the 1999 legislation to include studies by governmental and non-governmental organizations critical of the conference system in light of deregulatory experience. ${ }^{17}$

Second, the evolution of shipping policy is part of a larger history which mirrors the overall evolution of competition policy itself. Things are now different than they were in 1916, when the United States adopted its first shipping policy ${ }^{18}$-markets are different, industry is different, microeconomics is very different, and both the law and the law's esteem for the views of academic economists are different. The nature and prominence of statutory displacements of

15. See J.E. Davies, An Analysis of Cost and Supply Conditions in the Liner Shipping Industry, 31 J. INDUS. ECON. 417 (1983); William Sjostrom, Collusion in Ocean Shipping: A Test of Monopoly and Empty Core Models, 97 J. POL. ECON. 1160 (1989); J.A. Zerby \& R.M. Conlon, Joint Costs and Intra-Tariff Cross-Subsidies: The Case of Liner Shipping, 31 J. INDUS. ECON. 383 (1983). A body of positive empirical study also exists testing such matters as whether conference market shares correlate with freight rates. Compare N.R. Fox, An Empirical Analysis of Ocean Liner Shipping, 19 INT'L J. TRANSP. ECON. 205 (1992) (finding such a correlation) with PAUL S. CLYDE \& JAMEs D. REITZES, FEDERAL TRADE Commission, The EFFECTIVENESS OF Collusion UNDER ANTITRUST IMMUNITY 2 (1995) (finding no statistically significant correlation). As to whether rate variation is explained by particular cost factors, see Ingrid Bryan, Regression Analysis of Ocean Liner Freight Rates on Some Canadian Export Routes, 8 J. TRANSP. ECON. \& POL'Y 161 (1974); Fox, supra; Trevor D. Heaver, The Structure of Liner Conference Rates, 21 J. INDUS. ECON. 257 (1973); J. Janson \& D. Shneerson, The Effective Protection Implicit in Liner Shipping Freight Rates, 50 REV. ECON. \& STAT. 569 (1978), and as to whether conferences are able to price discriminate, see Fox, supra (finding evidence of discrimination); Bryan, supra (finding evidence of discrimination).

16. See GAO REPORT, supra note 5; George Deltas et al., American Shipping Cartels in the Pre-World War I Era, 19 RES. IN ECON. HIST. 1 (1999); J.W. Devanney III et al., Conference Ratemaking and the West Coast of South America, 9 J. TRANSP. ECON. \& POL'Y 154 (1975); Heaver, supra note 15.

17. See Fed. MAR. COMM'N, THE IMPACT OF THE OCEAN SHIPPING REForm ACT OF 1998 (2001) [hereinafter FMC, OSRA REPORT]; OECD FINAL REPORT, supra note 8; see also Fink et al., supra note 8 (econometric study by economists within Development Research Group, World Bank). Another interesting government report is a Federal Trade Commission empirical study prepared by two staff economists in 1995 . While they found no statistically significant correlation between conference market share and freight rates, they did find that freight rates were significantly lower where conference members were free to negotiate individual contracts directly with shippers. See CLYDE \& REITZES, supra note 15, at 2. Debate on these matters also contains less careful analyses, which often claim no more than the desirability of unrestrained competition and do not invoke empirical support. See, e.g., ADVISORY COMM'N ON CONFERENCES IN OCEAN SHIPPING, REPORT 165-166 (1992) (Separate Statement of Sen. Howard M. Metzenbaum) [hereinafter ADVISORY COMM'N REPORT]; Free Market Antitrust Immunity Reform Act of 2001: Hearing Before the House Committee on the Judiciary on H.R. 1253, 107th Cong. (statement of Charles James, Assistant Attorney General, U.S. Dept. of Justice, Antitrust Division); Free Market Antitrust Immunity Reform Act of 1999: Hearing Before the House Committee on the Judiciary on H.R. 3138, 106th Cong. (statement of John Nannes, Deputy Assistant Attorney General, U.S. Dept. of Justice, Antitrust Division).

18. The United States Shipping Act of 1916 granted shipping conferences conditional immunity from the domestic antitrust laws. 
antitrust in favor of regulation are also very different and, as will be seen, the story of the shipping exemption reflects the larger story of government efforts to cope with perceived problems of industrial organization.

What this history says about the way Congress works and about the use of abstract theory in the making of public policy is particularly interesting. There is a different and more plausible explanation for the plight of shipping than the one on which Congress based federal policy for nearly a century, and the reason for the continuing misunderstanding has been a predictive failure of economic theory. In short, a likely well-intentioned theoretical error by Congress--made at a time of historic, worldwide technological change and economic distress-gave rise to a situation in which carriers made substantial capital commitments to an inefficient market organization. Despite the flaws in this situation, the carriers' interests predominantly lay in preserving that status quo. As will be seen, it was quite easy for carriers and their academic supporters to explain theoretically that this inefficient organization was actually a natural one and to characterize the healthy process of forced exit that would result from deregulation as "destructive competition." Those efforts persist even now, despite the weighty deregulatory evidence that the theory was inaccurate. ${ }^{19}$

The remainder of the Article proceeds in five parts. Parts II and III summarize the history of the ocean shipping industry and the legal background of its regulation. Part III examines the economic situation and the state of economic thinking in the United States during the late nineteenth century, which explain the real origins of the policy. Parts IV and V proceed to the heart of the inquiry, which is a critical examination of the a priori theoretical claims upon which the policy was traditionally defended. In particular, Part V addresses a key theoretical question: if the shipping cartels permitted by U.S. policy were in fact harmful or poorly behaved, why did they not simply encourage disciplinary entry or cheating by their own members? Finally, Part VI addresses the key issue of policy left open in shipping regulation, namely whether the industry's transition to full competition should be completed. The evidence suggests that the collusive conduct still permitted continues to harm shippers and consumers, and there is no evidence of any pro-competitive upside to the collusive conduct except the same arguments used for years to defend the now defunct conference system itself. In conclusion, Part

19. See, e.g., World SHIPPING CoUnCIL, A REVIEW OF TRADE IN INTERnationaL MARITIME SERVICES-A PAPER BY WORLd BANK RESEARCHERS (2001) (arguing that, despite post- 1999 evidence, industry cannot perform under open competition). 
VI also attempts to place the story of shipping regulation into a larger historical picture.

\section{AN OVERVIEW OF OCEAN LINER SHIPPING}

Ocean liner shipping ${ }^{20}$ is by far the most common mode of international transport of goods ${ }^{21}$ and the chief means by which U.S. goods are shipped in foreign commerce. ${ }^{22}$ While it remains among the world's most vital industries and of great significance to the U.S. economy, ${ }^{23}$ the industry is now fairly concentrated worldwide, and none of its major participants are U.S. owned. All but two of the world's top twenty lines are based in Western Europe or Southeast Asia, and neither of the exceptions are U.S. owned. ${ }^{24}$

The U.S. government has directly regulated the industry for almost its entire existence. A chief feature of U.S. policy, which is currently embodied in the amended Shipping Act of 1984 (Shipping Act), ${ }^{25}$ is exemption from the antitrust laws for price-fixing cartels of ocean carriers. The policy's premise is the belief that problems of cost and capacity inherent in the trade can be resolved only by horizontal collusion. In place of antitrust, a federal agency, now known as the

20. "Liner shipping" is an industry term of art which means regularly scheduled common carriage of cargo by sea, which is now by far the predominant means of ocean transport but which has only existed since about the time of the Civil War. See Amos HeRman, SHIPPING CONFERENCES (1983).

21. See OECD FINAL REPORT, supra note 8, at 10; HERMAN, supra note 20, at 3 (noting that as of 1983 , over $80 \%$ of world trade by volume was carried by ship).

22. About $95 \%$ of U.S. foreign commerce is transported in ocean-going vessels, roughly half of which is carried on vessels covered by the Shipping Act and which enjoy that Act's antitrust exemption. See Papavizas \& Kiern, supra note 4, at 488 (citing 144 CONG. REC. S11301 (daily ed. Oct. 1, 1998) (statement of Sen. Hutchison)).

23. The United States ships nearly $\$ 2.4$ trillion in ocean-going exports annually, and three of the world's busiest ports are in the United States. See Container Traffic, CONTAINERISATION INT'L ONLINE, available at www.ci-online.co.uk (listing traffic at top port cities for 2004; top U.S. ports are Los Angeles, Long Beach, and New York/New Jersey).

24. See CONTAINERISATION INT'L ONLINE, Nov. 2003, available at www.cionline.co.uk (listing top twenty liner services by name and nationality). The two exceptions are the Israeli Zim and the U.K.-Canadian CP Ships, a subsidiary of Canadian Pacific. See id. Indeed, even American President Lines is a Singapore outfit. Moreover, in recent decades the U.S. flag fleet has declined significantly as a portion of worldwide capacity. Between 1970 and 1997 the U.S. flag merchant fleet declined from fifth to eleventh largest worldwide, see Timothy Semenoro, Comment, The State of Our Seafaring Nation: What Course Has Congress Laid for the U.S. Maritime Industry?, 25 TUL. MAR. L.J. 355, 366 (2000), and as of 1997 only $3.9 \%$ of the international trade of the United States by weight was carried in U.S. flag vessels, see id. at 366.

25. Shipping Act of 1984, Pub. L. 98-237, 98 Stat. 67 (1984) (codified at 46 U.S.C. app. $\S \S 1701-19(2006)$ ). 
Federal Maritime Commission (FMC), has regulated the industry. ${ }^{26}$ Always more or less controversial, this policy met the beginning of its end with the adoption of the Shipping Act, when ocean shipping became part of the deregulatory project of the early Reagan administration. ${ }^{27}$ A much more significant change followed in the Ocean Shipping Reform Act of 1998 (OSRA), ${ }^{28}$ and deregulatory efforts continue. For the first time in its history ocean shipping is becoming a free market.

Virtually from the time of European colonization, American shipbuilding was a success, ${ }^{29}$ and until the Civil War U.S.-built ocean vessels were preeminent. ${ }^{30}$ U.S. ship operation was equally successful. ${ }^{31}$ However, a series of events conspired against both

26. The policy's purpose was to protect the industry from perceived dysfunctions thought to inhere in its markets and to preserve a ready merchant marine for U.S. commerce and national emergency. See 46 U.S.C. app. $\S 1701$ (Shipping Act declaration of policy).

27. The series of legislation commonly known as "deregulation" actually began in the mid-1970s with the Railroad Revitalization and Regulatory Reform Act of 1976 , Pub. L. 94-210, 90 Stat. 31 (1976) (later strengthened by the Staggers Rail Act of 1980, Pub. L. No. 96-448, 94 Stat. 1895 (1980)), the Airline Deregulation Act of 1978, Pub. L. 95-504, 92 Stat. 1705 (1978), and, somewhat less deliberately, the Public Utility Regulatory Policy Act of 1978, Pub. L. No. 95-617, 92 Stat. 3117 (1978) (beginning deregulation of power industry). Deregulation of motor carriers quickly followed. Motor Carrier Act of 1980, Pub. L. 96-296, 94 Stat. 793 (1980). See also Darren Bush \& Carrie Mayne, In (Reluctant) Defense of Enron: Why Bad Regulation Is To Blame for California's Power Woes (Or Why Antitrust Law Fails To Protect Against Market Power When the Market Rules Encourage Its Use), 83 OR. L. REV. 207, 214-15 (2004) (discussing power deregulation); Clott \& Wilson, supra note 10, at 207-08 (discussing deregulation of transportation industries). Though deregulation began during the Carter administration, it was a core mission of the Reagan administration and much of the relevant effort was accomplished following Ronald Reagan's election in 1980. See BARRY Friedman, REgulation IN THE REAGan-Bush ERA: THE ERUPtion OF PRESIDENTIAL INFLUENCE (Bert A. Rockman ed., University of Pittsburgh Press 1995); cf. Christopher C. DeMuth, Deregulation Review, 53 ANTITRUST L.J. 189 (1984) (views of Reagan's chief deregulatory officer within Office of Management and Budget).

28. Pub. L. 105-258, 112 Stat. 1902 (1998).

29. The first American-built ocean-going sailing vessel was built in 1607 , the same year as the founding of the Jamestown colony. See Max Millikan, The Ocean Shipping Industry, in THE STRUCTURE OF AMERICAN INDUSTRY 422, 424 (Walter Adams ed., Pearson Prentice Hall 1950).

30. In the days of sail, American shipbuilding had natural advantages. Abundant timber and other raw materials, good harbors, and a great demand for shipping services made shipbuilding a principal colonial industry, and by the early eighteenth century, American-built ships were the best and cheapest in the world. See id. at $424-25$.

31. American ship operation also enjoyed special advantages. Prior to the Revolution, American shipping benefited from Britain's mercantilist economic policy. Manufacturing was restricted to the home country, so there was heavy exchange of American raw materials across the Atlantic. Likewise, following the Revolution, American shipping benefited greatly from the Napoleonic Wars, which kept the European belligerents occupied and left to American ships the cream of the neutral 
industries around the time of the Civil War; both industries declined dramatically at that time, and neither has ever fully recovered. A chief factor in this collapse was the advent of the steamship and its ability to provide regularly scheduled service, something that had not existed before ${ }^{32}$ For a variety of reasons, around this time British shipbuilders and operators began far to outperform their U.S. competitors, ${ }^{33}$ and the natural advantages of U.S. building and operation of sailing ships were rendered moot. Thus, it was that not long after the Civil War the United States and the world fully entered the new era of liner shipping. In any case, given the new difficulties they faced, since the late nineteenth century both U.S. ship building and operation have depended on federal subsidization for survival ${ }^{34}$

An important point in the following discussion is that the completely unregulated and unorganized period of the later nineteenth century is virtually the only time that liner shipping has been subject to genuine competition. Though empirical evidence from that period is sometimes marshaled in support of arguments about current policy, the circumstances of that time were very different from the present. First, the nascent liner industry was in the midst of its own explosive initial growth, as new carriers struggled for

traffic. See id. at 425; see also Paul Stephen Dempsey, Transportation: A Legal History, 30 TRANSP. L.J. 235, 269-70 (2003).

32. See Sjostrom, Modeling Competition, supra note 14, at 2 (citing GORDON H. BOYCE, INFORMATION, MEDIATION AND INSTITUTIONAL DEVELOPMENT: THE RISE OF LARGE-SCALE ENTERPRISE IN BRITISH SHIPPING, 1870-1919, at 24 (1995)).

33. First, the Civil War itself resulted in the destruction of a huge number of U.S. merchant vessels and also frightened owners into selling to foreign buyers. The combined result was a loss of nearly half of the U.S. merchant fleet. Second, the war occurred at the same time that steam powered ocean shipping had become economically viable and had shown its superiority to sail in both speed and regularity of service. By the time the war ended and the economy in general began to recover, U.S. efforts to develop a domestic steamship industry were frustrated by having lost the historic advantage over inputs (which had been wood and highly skilled domestic workers) and by serious barriers to U.S. access to steel. The U.S. steel industry had not kept pace with its British counterpart, and the western expansion of the U.S. railroad network created a great demand for domestic iron. The same demands arising from the British railway and industrial revolutions had already stabilized. Finally, at the same time that these events had conspired to make U.S.-built ships more expensive, capital was being diverted by the attractive returns in the newly developing railroad and manufacturing endeavors of the U.S. industrial revolution. See Millikan, supra note 29, at 427-29; Dempsey, supra note 31, at 270 (indicating that by the dawn of the twentieth century, the American merchant marine was nearly insignificant).

Even though domestic manufacturing later became more cost effective, by the time that had occurred, U.S. ship operators faced a different problem: the rising cost of American labor. Because U.S. law had mandated the use of at least some American officers and crew on American-flag vessels since 1789, see infra notes 113-14 and accompanying text, and because American operators necessarily had to employ more expensive American workers for shore-side support functions, U.S. shipping faced significant cost disadvantages from the turn of the twentieth century that have never abated. See Millikan, supra note 29, at 427-29.

34. See infra notes 113-30 and accompanying text. 
toeholds in the new market. Likewise, the industry faced competition from the collapsing sailing ship industry, which could remain in business only by charging desperately low rates. ${ }^{35}$

For almost as long as there has been liner shipping there have been conferences to govern it. A "conference" is any collection of carriers who, by formal agreement, decide to adhere to terms of service, including the fixing of rates. ${ }^{36}$ The first modern conference is believed to have been formed in 1875 over routes between England and India at the behest of leading English carrier companies. ${ }^{37}$ Thereafter conferences rapidly spread to most of the main world trade routes. ${ }^{38}$ Today there are around 150 shipping conferences in the international freight trade,$^{39}$ though active conferences exist almost exclusively among liner services for deep-sea general cargo transport. ${ }^{40}$ Conferences have dwindled in number both because of

35. See OECD FINAL REPORT, supra note 8, at 18.

36. See HERMan, supra note 20 , at 15 ; Thomas J. SChonnbaum, Admiralty AND MARITIME LAW 489 (Thomson West 1987) (4th ed. 2004); GERALD H. UlLMAN, U.S. REgulation OF OCEAN TRANSPORTATION UNDER THE SHIPPING ACT OF 19844 (1995). The Shipping Act adopts a similar definition for the conferences to which it applies. See 46 U.S.C. app. $\$ 1702(7)$ (defining conference as "an association of ocean common carriers permitted, pursuant to an approved or effective agreement, to engage in concerted activity and utilize a common tariff ...").

37. See B.M. DEAKIN \& T. SEWARd, ShIPPING ConfEREnCES: A STUdy OF ThEIR ORIGINS, DevelopMent AND ECONOMIC PRACTICES 23 (1973); Ullman, supra note 36, at 3-4. The conference in question, the England-Calcutta Conference, was created at the urging of the steamship leader Sir Samuel Cunard. See id. There is evidence of prototypical conferences existing as early as the $1850 \mathrm{~s}$, though they were not modern in the sense that they seem never to have agreed on prices or output. See Pirrong, supra note 14, at 117; Sjostrom, Modeling Competition, supra note 14, at 3 .

38. U.S. carriers followed the English example around the turn of the twentieth century, and the first major federal investigation of the phenomenon found that by 1914, nearly every trade route in both the foreign and domestic commerce of the United States and practically all established steamship lines had either been consolidated through stock ownership or were working in cooperation through conference agreements. See Report of the Committee on the Merchant Marine and Fisheries on Steamship Agreements and Affiliations in the American Foreign and Domestic Trade, H.R. Doc. No. 805, at 415 (1914) (a very influential document routinely referred to as the "Alexander Report," after its chair, Rep. Joshua Alexander) [hereinafter ALEXANDER REPORT]; See also ROYAL COMM'N ON SHIPPING RINGS, REPORT, CMND. No. 4668, at 36 (1909) [hereinafter RING COMM'N REPORT] (report of British investigative body, finding that as of the report's publication in 1909 the system of "[c]onferences ... ha[d] been expanded to many trades and over a wide area"). At least as far as rates are concerned, competitive services between the lines now in conference have ceased to exist, and in general competition from outside lines has been greatly restricted. The system has tended towards, and resulted in, a monopoly. Id. at 36; ADVISORY COMM'N REPORT, supra note 17 , at 5; ULLMAN, supra note 36, at 4; Pirrong, supra note 14, at 117 (stating that by the beginning of the twentieth century's second decade, conferences existed on all major liner shipping markets).

39. See OECD FINAL REPORT, supra note 8, at 19.

40. Conferences once existed among passenger liners and, strictly speaking, they are still permitted under U.S. law. However, as a practical matter cheap and 
deregulation and consolidation. ${ }^{41}$ Although the details of individual conference agreements vary, they are typically constructed around rate-fixing agreements. Some conference arrangements have gone so far as to allocate market shares among conference carriers, and some have included rebates to shippers, joint services, and door-to-door services. ${ }^{42}$

Liner shipping progressed under the conference system largely unchanged until the mid-twentieth century. Then, beginning in the 1950 s and 1960s, transportation companies began devising means for the easy transfer of freight among the various traditional modes of transportation-that is, among truck, rail, and ship. These efforts culminated in the development of "containerization," which employs large, standardized metal containers that can be carried on special semi-truck trailers, flatbed rail cars, or specialized ocean vessels called "containerships." The containers can be transferred easily among these modes. ${ }^{43}$ Cargo handling prior to containerization was

accessible air travel did away with passenger liner service. See HERMAN, supra note 20 , at $77-78$. Therefore, for practical purposes, "shipping conference" means a conference of deep-sea general cargo liner carriers. Shipping conferences exert little or no influence in coast-wise shipping, the bulk cargo trades, or amongst tramp carriers. Before the 1970s, long-existing conferences in the European coast-wise trade were common, but by the 1970s, they were essentially defunct. See DEAKIN \& SEWARD, supra note 37 , at 13 . Cartels in coast-wise shipping would not be permitted by U.S. law, which permits only conferences of shippers in "U.S. foreign commerce."

Likewise, of the three general categories of ocean shipping (dry bulk, liquid bulk, and general), conferences exist only among general cargo lines because most bulk shippers use either their own vessels or third-party providers that are chartered exclusively to one shipper. Only general cargo lines, by contrast, hold themselves out in the manner of common carriers, with regularly scheduled sailings available to all shippers at published tariff rates. "General cargo" includes all movements of cargo except the major bulk commodities, which consist of oil, iron and manganese ores, coal, grain, bauxite, and phosphates. See HERMAN, supra note 20, at 3; OECD FINAL REPORT, supra note 8, at 10, 19. See generally ADVISORY COMM'N REPORT, supra note 17 , at $17 \&$ nn.1-3.

Finally, no conference of tramp carriers appears ever to have exerted influence. A "tramp," as opposed to a liner, sails on an as-needed basis rather than according to regularly scheduled sailings for common carriage. A tramp or private carriage conference would not be permitted under U.S. law, which exempts only common carriers from antitrust regulation. Tramp cartels have probably only existed in Japan because they come within the shipping exception to Japanese competition law. ADVISORY COMM'N REPORT, supra note 17 , at 36 .

41. The effects of deregulation and consolidation are discussed infra at notes 66-112 and accompanying text. The number of liner conferences has fallen by more than half in the past thirty years; as recently as 1973 there were about 360 conferences worldwide. See DEAKIN \& SEWARD, supra note 37, at 13.

42. See OECD FINAL REPORT, supra note 8, at 22; Deltas et al., supra note 16, at 67.

43. Container carriage is thus to be distinguished from traditional "break-bulk" carriage, which was shipment of cargoes that literally had to be broken down from the truck or rail transport that brought it to port and then repacked in cargo ships. See ADVISORY COMM'N REPORT, supra note 17, at 17 \& nn.1-3. 
labor-intensive and costly 44 and limited optimal ship size. Accordingly, now virtually all cargo in the major U.S. trade lanes that can be moved by container is moved that way. ${ }^{45}$ Containerization has led to cost savings and efficiency, ${ }^{46}$ and it has impacted the development of intermodal services-the merging of different transportation modes into a seamless whole. Intermodalism has led to ever larger firms offering through-transport and logistical services. Those services allow shippers to arrange for shipment from point of origin to point of destination by one economic transaction on the basis of one set of international shipping documents. Shippers can also compare through-rates rather than the more complicated comparison amongst a set of possible unimodal legs of one shipment. ${ }^{\mathbf{4 7}}$

Containership vessels themselves remain in continual evolution, mainly by getting larger, and this too has had an impact on the organization of the industry. The marginal cost of adding more containers to a containership already sailing is low, so larger containerships are generally more efficient than smaller ones. Accordingly, shippers have continually added larger and larger ships. ${ }^{48}$ However, since very large containerships require huge capacity usage to operate efficiently, the use of so-called "hub-andspoke" arrangements is likely to continue its recent growth. Under the hub-and-spoke system, large ships serving main "trunk lines" are serviced by a number of smaller vessels operating regional feeder

44. See id. at 9 (noting that by 1960 labor costs in port accounted for $80 \%$ of the total cost of a typical voyage, and that following containerization, the average handling time per voyage fell from 157 hours to 31 hours). Break-bulk shipping also created large exposure to damage and pilfering. See id. at 17.

45. See id. at 17 n.3; OECD FINAL REPORT, supra note 8, at 14. Ocean shipping cannot be fully containerized because there are some cargoes, such as liquid, bulk cargoes, and autos and other self-propelled equipment, that cannot be shipped by container. See ADVISORY COMM'N REPORT, supra note 17, at 17 n.3. These cargoes are normally carried by charter or tramp, however, so it can be said that liner shipping is almost fully containerized.

46. Indeed, it is a basic maxim in transportation that unitization of cargo leads to increased efficiency, speed of handling, and reduced costs. See Richard W. Palmer \& Frank P. DeGiulio, Terminal Operations and Multimodal Carriage: History and Prognosis, 64 TUL. L. REV. 281, 284 (1989).

47. See ADVISORY COMM'N REPORT, supra note 17, at 9; Palmer \& DeGiulio, supra note 46 , at 283-84. Thus, the popular understanding of the organization of transportation services is currently at odds with its reality, and this misunderstanding is largely the result of conceptualization of modes of transportation contained in traditional regulatory schemes. That is, transportation services are normally conceived of as fitting in conceptually distinct modal cubbyholes such as ocean, rail, or truck transport, and these distinctions are driven at least in part by the fact that the different modes have been conceived by regulators as different. For two extremely thoughtful and comprehensive historical analyses of this phenomenon, see Arthur Donovan, Intermodal Transportation in Historical Perspective, 27 TRANSP. L. J. 317 (2000) and Palmer \& DeGiulio, supra note 46.

48. See OECD FINAL REPORT, supra note 8, at 15. 
routes. ${ }^{49}$ This trend may pose significant consequences for many port facilities and will affect the organization of the industry. ${ }^{\mathbf{5 0}}$

Finally, the incipient deregulation of ocean shipping, a development which has only just begun, may prove to be as significant an event as containerization and intermodalism. OSRA, which took effect in May 1999, remains the most significant step in U.S. policy thus far. Though it retained antitrust immunity for carrier agreements, for the first time in the history of U.S. shipping policy OSRA made it possible for any ocean carrier to negotiate independent service contracts with shippers. ${ }^{51}$ The terms of such service contracts may remain confidential, and conferences may not deter them in any way, either by action against any carrier ${ }^{52}$ or shipper. $^{53}$ In the roughly seven years since OSRA's enactment, the service contract has led to the virtual demise of the century-old conference system. The FMC now receives filings of nearly 50,000 new service contracts annually, ${ }^{54}$ a number that under prior

49. See id. at 17-18; Clott \& Wilson, supra note 10, at 213-15.

50. Already some ports, such as Singapore and Colombo, have developed specialized facilities to handle the transshipment of containerized cargo involved in such hub-and-spoke arrangements. Smaller ports, however, will be unequipped to perform large-scale transshipment operations and will have inadequate harbors to handle the largest containerships. See Clott \& Wilson, supra note 10, at 213-15. Therefore, small ports may increasingly be reduced to regional feeder facilities for their nearest major ports. Likewise, the growth in the size of containerships can only add to the rapid concentration of the industry, as the building of containerships already entails enormous capital outlay. See infra notes 130-145 and accompanying text. Furthermore, it has been suggested that the rise of hub-and-spoke arrangements may create market power on behalf of carriers, similar to the market power thought to have inured to airlines through hub airport arrangements following airline deregulation. See Clott \& Wilson, supra note 10 , at 214 . Whether this will occur remains to be seen.

51. A "service contract" is a contract between one or more shippers and one or more carriers or a conference in which the shipper commits to a certain volume of cargo over a fixed period of time and the carrier commits to a certain rate and level of service. See 46 U.S.C. app. $§ 1702(19)$ (2006); SCHOENBAUM, supra note 36, at 404.

52. Prior to OSRA, the Shipping Act had permitted service contracts but severely restricted their effectiveness. The Act: (1) permitted conferences to regulate or prohibit service contracting, (2) required that service contracts be filed with the Commission and made their terms available to the public, and (3) required that all similarly situated shippers be entitled to the same essential terms for a period of 30 days. See generally ADVISORY COMM'N REPORT, supra note 17, at 130-32.

Generally, prior to OSRA the conferences prohibited independent service contracting entirely. See FMC, OSRA REPORT, supra note 17, at 18; ADVISORY COMM'N REPORT, supra note 17, at 133 ("At present, no conference in the U.S. foreign trades permits its member lines to engage independently in service contract activity.").

53. See 46 U.S.C. app. $§ 1709(b)(3)$ (prohibiting retaliation against any shipper "because the shipper has patronized another carrier, or has filed a complaint, or for any other reason.").

54. See Fed. MAR. COMM'N, 41ST ANNUAL RePORT For FisCaL YeAR 2002, at 132 (2003), available at http://tinyurl.com/hxw3l [hereinafter 2002 ANNUAL REPORT]; FED. MAR. COMM'N, 40TH ANNUAL REPORT FOR FISCAL YEAR 2001, at 124, available at http://tinyurl.com/j48vb [hereinafter 2001 ANNUAL REPORT]; Fed. Mar. Comm'n, 39th Annual Report for Fiscal Year 2000, at 112 available at http://tinyurl.com/jhy6u 
regulation had been as low as 400 and averaged between 2,000 and $4,000 .{ }^{55}$ The FMC estimates that as much as $80 \%$ of cargo carried by conference members is now carried under independent service contracts. ${ }^{56}$ Moreover, though OSRA still permits conferences to establish "voluntary guidelines" to govern service contracting, the evidence suggests that the ability of conferences to control carrier behavior through these guidelines is dependent on market conditions-where demand or competition are slack, the guidelines have relatively little influence. ${ }^{\mathbf{5 7}}$

While it appears that the traditional conference system has collapsed under OSRA, carrier cooperation is still significant. Indeed, carriers continue to share price and customer information through socalled "discussion agreements," and through information sharing and voluntary guidelines, they likely have continued to exert some control over carrier behavior. This control is especially strong in times of excess demand, particularly as to the various surcharges and ancillary service terms typical of contemporary service contracts. ${ }^{\mathbf{5 8}}$ Moreover, carriers have increasingly turned to non-price operational agreements to organize their industry. In fact, operational agreements appear likely to replace the conference as the industry's

[hereinafter 2000 ANNUAL REPORT] (35,190 new service contracts filed in fiscal year 2000).

55. See ADVISORY COMM'N REPORT, supra note 17, at 133 \& table VIII-1.

56. See FMC, OSRA REPORT, supra note 17, at 20; see also OECD FINAL REPORT, supra note 8 , at 22 (noting that post-OSRA there has been a rapid and vast switch (200\% increase) to service contracts and that very little traffic (e.g., less than $10 \%$ of the U.S.-Europe traffic) now takes place directly under conference terms); EC Proposal, supra note 6, at 7 ("in today's market, conferences are not able to enforce the conference tariff [because] [t]he majority of cargo is carried under confidential individual agreements....").

Note that some portion of service contracts on file are actually between conferences and shippers. Conference service contracts differ from normal conference service because the contracts may deviate from rates and terms in published tariffs and state rates that are fixed for a specified term. But the FMC estimates that $98 \%$ of service contracts on file are independent. See FMC, OSRA REPORT, supra note 17, at 19.

57. See id. at 13-17. Demand will vary both according to (1) trade imbalances and currency fluctuation, and (2) underlying demand for particular cargoes. See infra notes 111-12 and accompanying text. The competitive environment of ocean shipping varies significantly from place to place. The most competitive trade lane faced by shippers in U.S. foreign commerce is between the east coast of the United States and Northern Europe. Under OSRA, the membership of the conference that traditionally dominated that market, the Trans-Atlantic Conference Agreement (TACA), fell from a high of seventeen members to a current low of seven. FMC, OSRA REPORT, supra note 17 , at 14-15. While TACA's seven members still hold $50 \%$ of the market share of North Atlantic shipping (a drop from their pre-OSRA high of $80 \%$ ), the market is saturated by independent contracts, and a huge portion of the transport, even by TACA's members, now moves under independent service contracts. See id. U.S. shipping in the Pacific, by contrast, remains comparatively uncompetitive. See id.

58. See infra notes $167-75$ and accompanying text. 
key organizational tool; they now constitute the majority of agreements on file with the FMC. 59

Two salient consequences of recent deregulatory experience are the increasing concentration of the industry ${ }^{60}$ and the rapid transition to non-price operational agreements among carriers and associations of carriers as a means of rationalizing capacity. Since 1995, seven principal mergers and more than thirty acquisitions have taken place. ${ }^{61}$ Thus, as of 2001, the top twenty liner operators accounted for $81 \%$ of the world fleet ${ }^{62}$ and $72 \%$ of world container capacity, and the five largest operators accounted for $34 \%$ of capacity. Though this trend began even before the Shipping Act, ${ }^{63}$ it appears to have accelerated since OSRA. Very similar results followed the deregulation of other U.S. transportation sectors. ${ }^{64}$

Likewise, the transition to non-price operational arrangements indicates a coming reorganization of the industry. No longer able to rely on legally-protected conference rate setting to stabilize capacity, carriers have turned to joint venture agreements and various other arrangements for the sharing of vessels and leasing of space on one another's vessels. These arrangements serve as an alternative to simply adding new ships and service strings, which tend to worsen overcapacity problems. As the FMC wrote in a recent report, "[n]o longer can the structure of liner shipping be viewed as fifty or so major carriers operating autonomously. It is more appropriate to view the industry as blocs of operational partnerships, with crisscross ties via space charters between many different members of different partnership blocs."65

In summary, the rise of contemporary ocean shipping can be understood in historical perspective as a sequence of four watershed events: (1) the advent of steam-powered shipping in the 1870 s, which made regularly scheduled shipping possible for the first time and almost immediately gave rise to the conferences; (2) the advent of containerization in the 1960s; (3) a transition currently underway to an intermodal or amodal conceptualization of global transport services, with an attendant industrial and regulatory reorientation;

59. See FMC, OSRA REPORT, supra note 17, at 26.

60. It was once thought that in the case of liner shipping, major concentration was unlikely for non-economic reasons: concentration would result in the extinction of individual lines and may not be acceptable to the governments of the flag states of the carriers involved. See Davies, supra note 15, at 433-34. Experience suggests this was incorrect.

61. See FMC, OSRA REPORT, supra note 17 , at 17.

62. See id.

63. See H.R. REP. 98-53(II), at 4 (1984).

64. See generally Clott \& Wilson, supra note 10 (noting significant concentration in airlines, trucking, and railroads following their deregulation in 1978 and 1980).

65. FMC, OSRA REPORT, supra note 17 , at 25. 
and (4) a transition currently underway to deregulation, which has already resulted in large organizational changes in the industry.

\section{LEGAL BACKGROUND}

For almost as long as shipping conferences have existed, they have been exempt from competition law both in the United States and elsewhere, ${ }^{66}$ and in most of the world they have gone completely unregulated. ${ }^{67}$ It so happens that liner conferences arose in U.S.

66. See S. REP. 105-61, at 2 (1997) ("All . . maritime nations allow shipping conferences to exist with immunity from application of the antitrust or competition law.").

Note that liner shipping in U.S. foreign commerce-the shipping to which the U.S. antitrust exemption applies-is not currently subject to any international regulation specific to shipping itself. A push for uniform international shipping regulation has long persisted, but it has been frustrated by parochial conflicts between developed countries and the developing world. Many developing countries, upon emergence from colonialism following World War II, found themselves at severe balance-of-payments disadvantages and as net consumers of shipping services. See Terry Marquez, Shipping, Competition and Dumping: The European Community's Liner Shipping Regulations, 23 TUL. MAR. L.J. 139, 150 (1998). Nearly thirty years ago, the United Nations Conference on Trade and Development (UNCTAD) attempted to address this conflict when it promulgated its Code of Conduct for Liner Conferences, UN Doc. TD/Code/11/Rev. 1 (1974), reprinted in 13 I.L.M. 917 (1974). Thus, the UNCTAD Code includes not only rules for the conduct of conferences but also major cargo sharing provisions intended to support the development of merchant fleets by developing countries. The UNCTAD Code was ratified by many nations but only with substantial reservations that have prevented it from being effectively implemented. See HERMAN, supra note 20, at 164-74; Marquez, supra, at 150. Though support remains for international regulation, see, e.g., HERMAN, supra note 20 , at $173-74$, this basic tension between the conflicting parochialisms of developed and developing countries makes it seem unlikely that any truly universal regulation will be forthcoming soon.

67. See H.R. REP. 98-53(I), at 9 (1984) ("Generally, ocean shipping is unregulated in the rest of the world. For the most part, the U.S. is alone in having a regulatory commission like the FMC."); GAO REPORT, supra note 5, at iv ("Most countries do not impose restrictions on the practices or organization structure of shipping conferences.").

U.S. shipping policy is unique in at least three respects: First, it requires that all conferences be "open." See 46 U.S.C. app. $\$ 1704$ (b)(2) ("Each conference agreement must... provide reasonable and equal terms and conditions for admission . . . to conference membership for any ocean common carrier willing to serve the particular trade or route."). Second, U.S. law makes all conference agreements and tariffs approved thereunder available to the public. See 46 U.S.C. app. $§ 1705$ (a) ("Within 7 days after an agreement is filed, the [FMC] shall transmit a notice of its filing to the Federal Register for publication."); id. $\S 1707(a)(2)$ (providing that conference "tariffs shall be made available electronically to any person, without . . limitation" for a "reasonable charge"). Finally, since OSRA, U.S. policy has mandated that conference members be free to enter into independent contracts with shippers on a confidential basis. See id. $\$ 1704(\mathrm{~b})(8)$ ("Each conference agreement must . . provide that any member of the conference may take independent action on any rate or service item 
commerce at around the time of the first U.S. antitrust legislation, and before Congress adopted the first U.S. shipping statute in 1916 the federal courts had found their conduct illegal under the Sherman Act. ${ }^{68}$ Conference activity was the subject of two major government investigations near the turn of the twentieth century, one in Britain ${ }^{69}$ and one in the United States, ${ }^{70}$ both of which recommended that conferences be tolerated but subject to some government oversight. ${ }^{71}$

upon not more than 5 calendar days' notice to the conference"); id. $\S 1707(\mathrm{c})(2)$ (requiring that service contracts "shall be filed confidentially with the [FMC].").

68. See U.S. v. Pacific and Arctic Ry. \& Nav. Co., 228 U.S. 87 (1912); U.S. v. Prince Line Ltd., 220 F. 230 (S.D.N.Y. 1915); U.S. v. Hamburg-Amerikanische PacketFahart-Aktien Gesellschaft, 200 F. 806 (S.D.N.Y. 1911). See generally HERMAN, supra note 20 , at 12 . Indeed, the Justice Department began Sherman Act prosecutions almost immediately after the conferences arose in the U.S. foreign commerce, even though they had already been found legal by the British government, see RING CoMM'N REPORT, supra note 38; ULLMAN, supra note 36, at 4, and by British courts, see The Mogul S.S. Co. v. McGregor, Gour \& Co., 15 Q.B.D. 476 (1995). See also HERMAN, supra note 20 , at $8-9$.

Even today, most conduct undertaken by conferences would be illegal were it not for the Shipping Act exemption. Both common tariffs and the pricing guidelines typical of recent practice would constitute per se illegal horizontal price-fixing. See WILLIAM C. HolmES, ANTITRUST LAW HANDBOOK 285 (Thomson West, 2006 ed., 2006). Allocation of customers or territories or restrictions on output (i.e., "capacity rationalization") likewise would be per se illegal. See id. at 322-23. Even mere exchange of price and customer data, another carrier conference practice in recent years, could well be per se illegal under the circumstances in which the conferences participate. See U.S. v. Container Corp. of Am., 393 U.S. 333 (1969); HolmES, supra, at 292-93. Even were a conference reconceived as some sort of joint sales agency, it would face significant antitrust risks. See U.S. Dept. of Justice and Fed. Trade Comm'n, Antitrust Guidelines for Collaborations Among Competitors $\$ 3.2$ (2000) ("labeling an arrangement a 'joint venture' will not protect what is merely a device to raise price or restrict output; the nature of the conduct, not its designation is determinative.").

69. The British government appointed the Royal Commission on Shipping Rings, often called the Ring Commission, in 1906 to study the effects of liner conferences and their practices. The Ring Commission issued an influential report in 1909. See RING COMM'N REPORT, supra note 38; HERMAN, supra note 20, at 11.

70. Some years after the Ring Commission issued its report, the House Merchant Marine and Fisheries Committee undertook its own investigation of the conferences. The Committee, usually referred to as the Alexander Committee after its chair, Rep. Joshua Alexander, issued its report in 1914. The report, still a basic instrument in shipping policy and the foundation for what would become the Shipping Act of 1916, is referred to as the Alexander Committee Report. See ALEXANDER REPORT, supra note 38 .

71. The Alexander Committee recommended the policy that became the 1916 Shipping Act. The Act followed the Committee's report very closely, differing only in certain details. See Edward Mansfield, The Federal Maritime Commission, in THE Politics of REgulation 42, 46 (James Q. Wilson, ed., 1980). The Ring Commission, for its part, was more sanguine about the conferences and recommended only that shippers' organizations be formed to counterbalance the power of the conferences and that the British Board of Trade keep conferences under review by requiring the filing of agreements and tariffs. See HERMAN, supra note 20 , at 11.

Ultimately, although both inquiries were concerned with suspicious ancillary conduct designed to frustrate new entry or enforce conference terms, they sanctioned 
Shortly after the U.S. investigation, Congress passed the Shipping Act of $1916,{ }^{72}$ which exempted liner conferences that operated in U.S. foreign commerce from federal antitrust laws for setting rates and other terms. ${ }^{73}$ The Act did, however, require conference agreements to be approved by the FMC's predecessor before they were lawful, and it prohibited certain practices thought to be harmful. ${ }^{\mathbf{7 4}}$

A word is in order about the historical circumstances surrounding the first U.S. shipping regulation in 1916 because a case will be made that the policy's whole history is based on a serious, though well-intended, turn-of-the-century congressional mistake. The original shipping regulation was adopted during World War I, but the war had little to do with its theoretical foundations. Rather, its rationale was developed during an extensive congressional inquiry that was completed by 1914, well before U.S. involvement in the hostilities. ${ }^{75}$ The real intellectual roots of shipping policy lie further back, in the economics and history of nineteenth century business. Of chief significance was the fact that economic times were bad, and they had been for many years throughout the economies of the North Atlantic. ${ }^{76}$ Two commonly held explanations for economic woe were

the existence of the conferences because they believed that, without private coordination, the industry would be subject to chaotic rate wars. In particular, both inquiries were interested in the use of deferred rebates and other contract schemes to ensure shipper loyalty, and the use of so-called fighting ships, which were ships employed to forestall entry by non-conference carriers by underselling any would-be entrant, even at predatorily low prices. The fighting ship's losses would be spread across a conference's members. See HERMAN, supra note 20, at 11-13. By the time of the Alexander Committee Report, fighting ships had already been held illegal under the Sherman Act. See U.S. v. Hamburgh-American S.S. Line, 216 F. 791 (S.D.N.Y. 1914).

The concerns of the government inquiries were predominantly economic but were seemingly moral as well. The Alexander Committee, for example, spoke of its "desire to eliminat[e] ... secret arrangements and underhanded methods of discrimination." H.R. Doc. No. 805, at 416 (1914).

72. Pub. L. 87-254, 39 Stat. 728 (1916)

73. See generally ULLMAN, supra note 36 , at 4-6.

74. For example, it prohibited price discrimination between similarly situated shipper customers and prohibited artificial entry barriers such as the fighting ship. See supra note 72.

75. Namely, the original 1916 Shipping Act followed very closely the recommendations of the Alexander Committee, which was completed well before U.S. involvement in World War I. See Mansfield, supra note 71, at 47-48; supra note 72 . That is not to say that the war was irrelevant. The war led to drastic increases in shipping rates to freight in U.S. trades, and therefore, it focused public concern on the competitiveness of shipping markets. Accordingly, the war likely made passage of the law possible. The Shipping Act bill was approved along almost exclusively party lines; it was approved almost exclusively by Democrats and opposed almost exclusively by Republicans. See id.

76. See generally Daniel T. Rodgers, Atlantic Crossings: Social Politics IN A Progressive AGE (Belknap Press of Harvard Univ. Press 1998); Tony Freyer, The Sherman Antitrust Act, Comparative Business Structure, and the Rule of Reason: 
(1) the decreasing productivity of labor and its purportedly increasing share of the cost of doing business, ${ }^{77}$ and (2) the theory of "destructive competition," which held that where fixed costs were high, as they were thought to be in the many capital intensive industries of the technologically evolving economy, open competition would produce rate war and inevitably lead either to monopoly or the destruction of all competitors. ${ }^{78}$ Moreover, a very large wave of business mergers also began around 1895. In the span of about ten years, mergers resulted in the largest consolidation of business in Western history ${ }^{79}$ and contributed greatly to the common view that open competition no longer worked. 80

Accordingly, by the time of the 1914 congressional investigation, a commonly held view was that the businessman's only hope for survival would be either consolidation or horizontally collusive output constraints, because competition would be destructive in many sectors, and the only variable within the control of business managers was output. ${ }^{81}$ Perhaps along with the American bent for social ordering by private association, ${ }^{82}$ by 1914 the rhetoric of the

American and Great Britain, 1880-1920, 74 IowA L. REV. 991, 994 (1989); James Livingston, The Social Analysis of Economic History and Theory: Conjectures on Late Nineteenth Century American Development, 92 AM. HIST. REV. 69, 72-73 (1987); Jeffrey G. Williamson, Watersheds and Turning Points: Conjectures on the Long-Term Impacts of Civil War Financing, 34 J. ECON. HIST. 636 (1974); Jeffrey G. Williamson, Late Nineteenth-Century American Retardation: A Neoclassical Analysis, 33 J. ECON. HIST. 581 (1973).

77. See Livingston, supra note 76 , at $72-73$; see also Williamson, Late Nineteenth-Century, supra note 76, at 583 (noting quantitative evidence that between Civil War and 1900, American labor productivity decreased).

78. By the time of the Shipping Act, economists had developed a well-polished theory of destructive competition, under which it was thought that in any high fixedcost industry, competition would lead either to monopoly or inevitable rate war causing the demise of all competitors. See generally NAOMI R. LAMOREAUX, THE GREAT MERGER MOVEMENT IN AMERICAN BUSINESS, 1895-1904 (1985).

While the Committee took no evidence from any economist and cited no work of academic economics, see the ALEXANDER REPORT, supra note 38 , at 2-7 (listing the Committee's sources of information).

79. See LAMOREAUX, supra note 78, at 2-5 (noting that between 1895 and 1904, some 1800 U.S. firms disappeared into consolidations, the resulting firms sometimes holding very large market shares).

80. See LAMOREAUX, supra note 78; Donald Dewey, The Economic Theory of Antitrust: Science or Religion?, 50 VA. L. REV. 413, 417 (1964) ("of the developments undermining the faith in laissez faire, the most important was the unprecedented wave of mergers that swept the economy between 1895 and 1905.")

81. That is, it was thought that a chief problem was the rising cost of labor but that labor's power was also growing and was beyond the control of the capital class. See LAMOREAUX, supra note 78.

82. See AlEXIS DE TOCQUEVILLE, DEMOCRACY IN AMERICA 513-17 (George Lawrence, trans. Doubleday Anchor Books ed. 1969) (1839).

Americans of all ages, all stations in life, and all types of disposition are forever forming associations. . . . In every case, at the head of any new undertaking, 
benevolent cartel was second nature in business ${ }^{83}$ and had led to official sanction from government in a variety of ways. ${ }^{84}$ Thus, when shipping policy was first theoretically formulated, practical circumstances and economic theory had already led to massive industry consolidation, open and unapologetic efforts to regulate the economy through multilateral private agreements, ${ }^{85}$ and the spread of significant numbers of purportedly legal trade associations for the coordination of business. ${ }^{86}$ Government sanction of shipping cartels therefore seemed only natural, and sweeping antitrust exemptions for other transportation sectors followed shortly thereafter. ${ }^{87}$

where in France you would find the government or in England some territorial magnate, in the United States you are sure to find an association.

Id.

83. Businesses had significantly cartelized the American economy in a variety of sectors throughout the late nineteenth century, and in particular pooling agreements and output-limiting cartels were common in railroads and shipping. Thus, by 1916, the psychological commitment of businesspeople to associationalism was deep and thorough-going, and it was a major article of faith at least as early as the legislative consideration of the 1914 antitrust amendments. Famously, the Gary dinners, informal gatherings of steel industry executives to coordinate business affairs arranged by Elbert Gary, had begun in 1907 and were well known to the public at that time. See John D. Clark, The Federal Trust Policy (1931). Likewise, a theoretical work by the antitrust lawyer Arthur Eddy, which was nothing short of a blockbuster and lay the intellectual foundations for the associationalist movement that was to culminate in the National Industrial Recovery Act, was published and widely read in 1912. See ARTHUR JEROME EDDY, THE NEW CoMpetiTiOn (D. Appleton 1912); see also Tosdal, supra note 2 (describing Eddy's book and the impact it had on business people's thinking).

In any event, testimony surrounding the 1914 antitrust amendments involved a fair bit of this thinking and included explicit requests that any modifications to the Sherman Act permit either open freedom to fix prices or at least provide for a regulatory agency that could pre-approve some forms of cartel agreement. See CLARK, supra at 139-64.

84. Prior to the National Industrial Recovery Act, and aside from the antitrust exemptions adopted in the transport regulation regimes, the most significant and visible policy was the official support given trade associations under the Commerce Secretariat of Herbert Hoover. See RoberT F. Himmelberg, The Origins of the National REcovery Administration: Business, Government, AND THE TRADE Association ISSUE, 1921-1933 (1993); Ellis W. Hawley, Herbert Hoover, the Commerce Secretariat, and the Vision of an "Associative State," 1921-1928, 61 J. AM. HIST. 116 (1974). This "associationalist" policy culminated in the abortive National Industrial Recovery Act.

85. See Alfred D. Chandler, Jr., The Visible Hand: The Managerial REVOLUTION IN AMERICAN BUSINESS 122-44 (1977); HERBERT HOVENKAMP, ENTERPRISE AND AMERICAN LAW, 1836-1937, 145-48 (1991); Robert L. Rabin, Federal Regulation in Historical Perspective, 38 STAN. L. REV. 1189, 1199-1200 (1986); cf. Tosdal, supra note 2, at 331-34 (reviewing the rapid World War I-era rise of the "open price association" form of horizontal cartel, devised by antitrust lawyer Arthur Jerome Eddy).

86. See Tosdal, supra note 2, at 331-34.

87. See Dempsey, supra note 31 , at $281-89$. 
There is an alternative explanation of the industry and its problems at that time, and that explanation will be laid out in due course, but first it will be useful to review the industry's economic performance since that time. Experience and changing policy priorities have led to several modifications in this regulatory scheme, ${ }^{88}$ culminating in the Shipping Act, ${ }^{89}$ which, as amended by OSRA, remains the law of the United States. In short, current U.S. law permits liner carriers within the coverage of the Shipping Act ${ }^{90}$ to fix their rates and essentially any other terms of service or operations, ${ }^{91}$ so long as such agreements are first filed with the FMC. ${ }^{92}$ Upon filing, the FMC makes the agreements available to the public. ${ }^{93}$ Though filed agreements and activity related to them are

88. Other than special provisions made during wartime, U.S. shipping policy has undergone three major modifications since 1916. The first major amendment was made to undo a decision of the U.S. Supreme Court. The Court's decision in 1958 in Fed. Mar. Bd. v. Insbrandtsen Co. 356 U.S. 481 (1958) held dual-rate contracts illegal. This decision, which proved controversial, was reversed by Congress in 1961. See Act of Oct. 3, 1961, Pub. L. 87-346 (1961). See generally GAO REPORT, supra note 5, at 7.

The second major modification came twenty years later in the Shipping Act of 1984 . One purpose of the 1984 Act was to experiment with limited deregulation of the industry, as economists and regulators had begun to seriously question the economic premises on which the exemption had been founded. See generally H.R. REP. 98-53(II), at 8-10 (1984). The Act began this deregulatory process by, among other things, introducing a limited form of service contracting.

The 1984 Act also addressed several concerns unrelated to deregulation, such as a measure to address the FMC's long delays in approval of filed tariffs and carrier agreements, see infra notes 119-36, and a provision to undo another controversial Supreme Court decision, FMC v. Aktienbolaget Svenska, 390 U.S. 238, 243 (1968) (holding that the "contrary to the public interest" standard of the 1916 Act required disapproval by FMC of any carrier agreement that would violate U.S. antitrust law, unless the carriers could carry the burden of proving that the challenged agreement "was required by a serious transportation need, necessary to secure important public benefits or in furtherance of a valid regulatory purpose of the Shipping Act."). See H.R. REP. 98-53(II), at 8-10 (1984); ADVISORY COMM'N REPORT, supra note 17, at 24-25; Palmer \& DeGiulio, supra note 46, 317-18.

The third and final major modification took effect under OSRA in 1999, as explained in the text to follow.

89. 46 U.S.C. app. $\S \S 1701-19$.

90. See 46 U.S.C. app. $§ 1702(6)$ (defining "common carriers" to which the Act applies as those "provid[ing] transportation by water . . . between the United States and a foreign country.").

91. See id. $\S 1703(\mathrm{a})$ (defining "agreements" within the scope of the Act and therefore those exempt from antitrust upon filing with the FMC).

92. See id. \$ 1704(a) (setting forth filing requirements). Agreements no longer need be approved by the FMC. They become effective automatically forty-five days after filing, see id. $\$ 1704$ (providing that the FMC can summarily reject agreements only for technical errors); the procedure is modeled on merger pre-clearance under the Hart-Scott-Rodino Act, H.R. REP. 98-53(II), at 10 (1984). This change grew out of frustration from all sides with delays in the FMC agreement review process, which reached critical proportion in the $1970 \mathrm{~s}$ and was believed to have become an impediment to commerce. See id. at 7.

93. See 46 U.S.C. app. $\$ 1705$ (a) (requiring FMC to publish all filed agreements in Federal Register). Though tariff rates no longer need be filed, conferences and 
exempt from antitrust laws, ${ }^{94}$ the Shipping Act adopts something of a surrogate federal competition policy by imposing technical requirements on some agreements, prohibiting certain conduct, ${ }^{95}$ and empowering the FMC to enforce a general minimum standard of competitiveness. ${ }^{96}$ Traditionally there has been doubt, however, about the agency's ability to enforce these rules. ${ }^{97}$ It seems likely that throughout most of its history the industry has been subject to very little formal constraint on anticompetitive activity. ${ }^{98}$

Though in its structure and superficial details the regime resembles prior law, shipping policy has been dramatically redesigned in the past several years, mainly by way of OSRA. OSRA's chief innovation was the introduction of independent service contracting, the terms of which may be kept confidential, and against which conferences are not permitted to take any punitive action. ${ }^{99}$ Thus, although in principle conferences may still collectively fix rates and other terms, their agreements are no longer binding. In other

carriers must still make them publicly available in electronic form. See id. $\$ 1707$. A "tariff" is a schedule of rates for particular services offered to the public on a common carriage basis. See SCHOENBAUM, supra note 36, at 493.

94. See 46 U.S.C. app. § 1706.

95. First, the Act imposes a series of formal requirements for various kinds of agreements, such as "reasonable and equal terms . . for admission" to a conference, permission for conference members to withdraw without penalty, see id. $\S 1704(\mathrm{~b})$, and mandatory internal procedural protections, $i d$. Second, the Act adopts a list of explicit prohibitions on anticompetitive conference activities, such as unreasonable refusal to deal, predation against non-members, and allocation of customers, see id. $\S 1709$ (c).

96. Under $\$ 1705(\mathrm{~g})$ the Commission can seek to enjoin any filed agreement if "the agreement is likely, by a reduction in transportation service or an unreasonable increase in transportation cost" to result in competitive injury. However, the Commission must seek such an injunction through an action in the District Court for the District of Columbia; it cannot simply issue such an injunction on its own. See id. $\S$ 1705(h). The Commission can reject carrier agreements of its own accord only if they violate the technical requirements in $\$ 1704$.

The FMC in fact has never used its power to challenge unreasonable service or cost agreements as it exists under $\S 1705(\mathrm{~g})$ of the 1984 Act and OSRA, see ADVISORY COMM'N REPORT, supra note 17 , at 25 , and $\S 1705(\mathrm{~g})$ may not be enforced by private action, see 46 U.S.C. app. $\$ 1710$ (a) (providing that private persons may file complaint with the FMC for any violation of the Shipping Act except for violations of $\$ 1705(\mathrm{~g})$ ). The Act also forbids third-party intervention in Commission actions under $\$ 1705(\mathrm{~g})$, see id. $\S 1705(\mathrm{~h})$, and prohibits private causes of action under the antitrust laws against any other conduct the Act prohibits, see id. $\$ 1706(\mathrm{c})(2)$.

However, the Commission has worked with conferences on several occasions to modify troublesome aspects of agreements rather than proceeding to litigation, and the Commission has long believed that overcapacity in U.S. foreign shipping lanes operates to constrain supracompetitive price increases. See ADVISORY COMM'N REPORT, supra note 17 , at 25 .

97. See, e.g., Mansfield, supra note 71, at 46-61.

98. See id. (detailing evidence of FMC's inability to effectively police filed agreements and tariffs according to any substantive standard).

99. See supra notes $165-70$ and accompanying text. 
words, as a practical matter U.S. shipping is now a free market, except for the fact that carriers are not subject to antitrust. Accordingly, they may share price information, agree to non-binding guidelines for rates and terms of service, adopt common non-binding tariffs, etc. ${ }^{100}$

It seems unlikely that deregulation will end with OSRA. Efforts have been made several times since 1999 to do away with the U.S. antitrust exemption almost entirely, ${ }^{101}$ and though the matter has not yet reached floor consideration, it has had significant support. ${ }^{102}$ Certain other influential calls for an end to the exemption also have emerged, most notably from the OECD and from economists at the World Bank, ${ }^{103}$ and even now several other maritime nations are reconsidering their own liner shipping exemptions. ${ }^{104}$

\section{DESIRABILITY OF THE EXEMPTION: THEORY AND EMPIRICAL EVIDENCE}

Arguments in support of the antitrust exemption take a variety of forms, but their gravamen is that special cost and capacity problems of liner shipping make it impossible for the industry to arrive at efficient levels of supply, and that unbridled competition will lead to destructive competition, instability of prices, and undesirable oligopoly. ${ }^{105}$

It is widely agreed that liner shipping of general cargo is beset by unusually high fixed costs ${ }^{106}$ and that a liner carrier's initial capital

100. The Shipping Act and OSRA each introduced other innovations unrelated to the antitrust exemption or contracting and rate-setting practices, notably provisions intended to encourage the transition to multimodalism. See Palmer \& DeGiulio, supra note 46.

101. See Free Market Antitrust Immunity Reform Act (Fair Act) H.R. REP. No. 3138 (1999) (first introduced), H.R. REP. No. 1253, 107th Cong. 2001 (reintroduced). The Fair Act would phase out the U.S. antitrust exemption as to all ocean shipping agreements except those among marine terminal operators. See id.; H.R. REP. NO. 3138 (2000).

Indeed, even OSRA and the 1984 Act were compromise measures between carriers and a variety of parties who sought to eliminate the antitrust exemption altogether. See Bliss \& Beddow, supra note 4, at 357-60; Papavizas \& Kiern, supra note 4, at 48889.

102. See sources cited supra note 5 .

103. See OECD FINAL REPORT supra note 8; Fink et al., supra note 8.

104. See OECD FINAL REPORT, supra note 8, at 19.

105. See infra notes $126-28$ and accompanying text.

106. It is estimated that in liner shipping of general cargo, $65-90 \%$ of all costs are fixed. This problem arises both from the cost of contemporary container vessels and from the committed nature of scheduled transport services, which renders many operating costs invariant in the short run. See Davies, supra note 15, at 417 . As Davies notes, liner shipping, especially since the advent of containerization, demands a greater capital stake than other shipping sectors, because containerized cargo vessels 
investment is very large. ${ }^{107}$ Moreover, liner shipping entails a large complement of "avoidable fixed" costs or "non-cargo" costs-that is, costs that do not vary with the quantity of cargo carried but that are not incurred until a voyage is embarked upon. ${ }^{108}$ A related problem is overcapacity. No one doubts the industry has faced overcapacity problems, ${ }^{109}$ and they might be a consequence of high fixed costs. ${ }^{110}$ Cost problems have become only more acute with the advent of containerization and the increased scale economies it engenders. ${ }^{111}$

are by far the most expensive to build. See id. Moreover, once a schedule has been agreed upon, cost items such as fuel, crew wages, subsistence, maintenance, and repair, which might be regarded as variable in other industries, become fixed and cannot be avoided within the short run planning horizon. See id. at 418 . The only costs typical in general cargo ocean shipping which are truly variable are (1) commissions paid to agents who secure cargo, and (2) actual handling costs. See id.

107. This is so not only because the individual ships are expensive but because the maintenance of scheduled service at typically demanded frequencies requires not one ship, but a fleet of them, plus all the appurtenant equipment and shore-based capital infrastructure they require (containers, cranes, etc.). See id. at 418-19. Davies calculated that the minimum capital outlay to establish a new entry in the United States-Far East trade, where a minimum fleet size was estimated to be five vessels, would be on the order of $\$ 374$ million in 1978 dollars, even ignoring completely the costs of maintaining the shore-based administrative support such a fleet would require.

108. Most of these costs are outside the control of ship owners, and some of them are the subject of regulatory price controls. In the United States, this would include wage rates of U.S. officers and crew, the employment of which is mandatory on U.S.flag vessels. Carriers therefore face significant limitations in their ability to cut operational costs even when they do so under pressure of price competition. Such costs also include most obviously the substantial administrative and marketing organization a liner fleet requires, which, given the committed nature of scheduled transport services, is largely fixed in the short run, see Davies, supra note 15, at 418-19, as well as operational costs that are committed as soon as sailings are scheduled, including fuel, insurance, crew wages and costs, and maintenance, see HERMAN, supra note 20, at 29-30.

109. See S. REP. No. 105-61, at 1-2 (1997) (noting the industry's "chronic carrier conditions of overcapacity"); H.R. REP. 98-53(II), at 5 (1984) ("Almost all studies agree that the industry is suffering from overcapacity.").

110. Large fixed costs naturally entail significant returns to scale, and as a result a larger ship is normally more efficient. However, the fact that liner service by definition requires ships to sail regardless of how much unused capacity they may contain creates a perpetual risk of underutilization. Moreover, ships are durable and exceptionally long-lived assets, so even as more modern vessels enter the market, older vessels may be resold at distress prices and remain in service. See ADVISORY COMM'N REPORT, supra note 17 , at 68 . Further, while overcapacity may be manageable in some industries, it is a particular problem in liner shipping. Because a carrier's costs are predominantly fixed, the marginal cost of exploiting unused capacity within each particular ship is very low. Indeed, a particular carrier's cost functions are peculiar. Namely, average cost constantly decreases over the entire capacity of a particular ship, but capacity beyond full utilization of a given ship causes a sharp spike in average cost as the costs of an additional sailing are incurred, but then decreases constantly across the full capacity of the added ship. Therefore, overcapacity can and does result in rate war. See id at 68 .

111. See id. 
As a separate cause of overcapacity, the industry faces periodic bouts of slack and asymmetrical demand, which are driven by inevitable currency fluctuations and international trade imbalances; thus, the industry faces problems in forecasting needed capacity. ${ }^{\mathbf{1 1 2}}$

In essence, the question for the remainder of this Article is whether these economic problems legitimate capacity rationalization by horizontal price and output restraints. That is, do they justify the industry's ongoing statutory antitrust exemption?

\section{A. Capacity Rationalization and Unstable Price}

While the industry surely has suffered overcapacity, there are competing explanations for this phenomenon. It may be, as the industry argues, due to organic features of liner shipping. However, at least some of the existing overcapacity is attributable not to endogenous market phenomena but instead to subsidization of shipyards and preferential treatment of national flag carriers shown by many countries. ${ }^{113}$ Second, there is reason to believe that the

112. Because demand is derivative of demand for the goods to be shipped, it varies according to currency fluctuations and changing trade imbalances generally. See HERMAN, supra note 20, at 30-31. Demand for shipping also varies in some trade lanes as a consequence of seasonal variations in outputs of certain national commodities, particularly agricultural commodities, see Davies, supra note 15, at 432 (noting that demand for outbound shipping from New Zealand varies considerably by season owing, to that country's large meat exports), and because of institutional factors such as import quotas, export subsidies, cargo preference rules, and so on, see Clinton $\mathrm{H}$. Whitehurst, Jr., The Merchant Marine Act of 1936: An Operational Subsidy in Retrospect, 1 J.L. \& ECON. 223 (1958). During such trade imbalances, a carrier cannot ensure the same degree of capacity utilization in both directions of a voyage and therefore will suffer less efficient operation in one direction. See FMC, 2002 ANNUAL REPORT, supra note 54, at 23-24. In fact, U.S. carriers have faced slack demand for outbound services for several years, and the imbalance has grown each year since 1995 . See FMC, OSRA REPORT, supra note 17 , at 12-13.

113. Both shipbuilding and ship operation have long been subsidized by the U.S. government, as they are in many countries, for domestic protectionist reasons, for the felt need to preserve ready access of domestic industry to merchant marine, and for national security reasons. Subsidization is believed to have contributed to overcapacity. See ADVISORY COMM'N REPORT, supra note 17, at 58, 68-69; OECD FINAL REPORT, supra note 8, at 71 ("[T]here are many underlying reasons for ... overcapacity, including state support for shipbuilding leading to exceptionally low ... costs for new buildings.").

The U.S. government began subsidizing domestic shipbuilding and operation almost immediately after independence and it has continued ever since. By a law of 1789, American registry was restricted to vessels owned by U.S. persons. The Navigation Act of 1817 reserved the coastal trades for U.S. flag vessels, and mail subsidies were established in 1845. At the time of their enactment, none of these protections or subsidies was really needed for protectionist purposes because of the continued native advantages of U.S. industry. Rather, they were retaliation for similar policies of other maritime nations. In fact, they were long bitterly opposed by U.S. ship operators who wanted access to the foreign-built ships that had become cheaper due to the rising cost of U.S. labor. At around the time of World War I, when the shipping 
carriers themselves have deliberately contributed to capacity problems through the inefficient service competition typical of regulated or price-stabilized industries. ${ }^{114}$

Carriers have also argued that without collective rate setting, destructive competition will lead to unstable prices. ${ }^{115}$ While some customers have also expressed such a fear, ${ }^{116}$ it is not obvious that price volatility would be inefficient. Fluctuating prices are characteristic of many industries that are subject to antitrust laws, ${ }^{117}$ and in liner shipping they might simply reflect sensitivity to changing supply and demand. Moreover, there is evidence that the conference system actually promoted rate instability, especially in trades with less competition. ${ }^{118}$

\section{B. The Theory of the Empty Core}

The exemption's academic proponents have urged a theoretical re-tooling of the basic argument of destructive competition or capacity rationalization, known as the "theory of the empty core." In principle the argument is simple, and if there are industries in which empty cores can exist, the liner shipping industry should be a good candidate. The argument is that special cost or technological

industry's economic circumstances had changed significantly, ship operating interests finally gave up their effort for such a "free ship" policy and turned instead to seeking direct federal subsidization of ship operation. See generally Millikan, supra note 29, at 426-31.

114. If in fact conferences were able to maintain supracompetitive prices under the conference system and were able to contain internal cheating and lower-price entry, then conference members have little basis on which to compete with one another except through improved service, which, as a practical matter, means either more ships or more frequent sailings. See GAO REPORT, supra note 5, at ii-iii. Devanney et al. found empirical support that open conferences which, unlike closed conferences, have difficulty controlling capacity lead to inefficient service competition. See Devanney et al., supra note 16 , at 162 \& n.8. Increased capacity, other things being equal, necessarily means higher costs due to lower capacity utilization. See id. Conference members, however, can still recoup the attendant loss if they are able to charge artificially inflated rates.

115. See ADVISORY COMM'N REPORT, supra note 17, at 69.

116. See id.; GAO REPORT, supra note 5, at v.

117. See ADVISORY COMM'N REPORT, supra note 17, at 69.

118. See OECD FINAL REPORT, supra note 8 , at $44-45$ (noting that, according to shipper responses to an OECD survey, annual rate changes averaged $5-10 \%$ in most trades, with $30 \%$ changes not uncommon and some changes as high as $200 \%$ ). This deliberate instability was inherent in the traditional common tariff system itself, under which rates could be and frequently were unilaterally changed by the conferences, a process known as the "general rate increase" (GRI). Under service contracting, which has largely replaced the tariff system, rates are typically fixed for specified periods. Long-term contracts are a well-known means by which to protect against price instability and are used in a variety of industries. See ADVISORY COMM'N REPORT, supra note 17 , at 69 . 
problems in some markets make it impossible for competition to produce a stable long-run equilibrium price.119 A market has a "core" if there is a set of transactions between buyers and sellers such that there are no other transactions which could make some of the buyers or sellers better off. A basic implication of microeconomics is that such a core will survive in a competitive market where all firms are making zero economic profits. In a market where the core is empty, no coalition of firms will be able to persist at zero profit; some firm will always eventually earn a surplus and thereby attract entry, but because the core is empty, the new entry will result in all firms suffering losses. Likewise, because the core is empty, when firms exit due to economic losses, the remaining firms will again be able to earn greater than zero profit. ${ }^{120}$

Liner shipping markets could once have been thought to contain empty cores. Because the entry of even one new ship expands capacity not just incrementally but by the entire capacity of that new ship, existing firms earning a surplus will attract new entry that may automatically lead to overcapacity. ${ }^{121}$ The entry is therefore likely to

119. Specifically, empty cores are said to be possible in markets which have some or all of the following characteristics: (1) uncertain demand, (2) scale economies in production, (3) avoidable supply costs, (4) products that cannot be stored cheaply, (5) fixed firm capacities, and (6) firm capacities that are large relative to demand. See John S. Wiley, Antitrust and Core Theory, 54 U. CHI. L. REV. 556, 565 (1987). Ocean liner shipping arguably suffers all of these, depending on just how seriously capacity is fixed. Carriers and advocates of the antitrust exemption long asserted that capacity was tightly fixed because any change in capacity seemed to require purchase or sale of an entire ship. Deregulatory experience, however, has shown that carriers can manage their capacity easily, efficiently, and with suppleness through non-price operational agreements. Indeed, as will be explained, this turns out to be a major reason to doubt that empty cores characterize ocean shipping markets.

120. Empty core theory was first derived in the abstract by economist Lester Telser of the University of Chicago and later applied (sometimes by Telser's own doctoral students) to a variety of practical situations, including liner shipping. The explanation above is taken from the rendition in the OECD report. See OECD, FINAL REPORT supra note 8, at 61-62.

For more formal theoretical explanations, including several attempted applications to liner shipping, see LESTER G. TELSER, ECONOMIC THEORY AND THE CORE (1978); Varouj A. Aivazian \& Jeffrey L. Callen, The Coase Theorem and the Empty Core, 24 J.L. \& ECON. 175 (1981); George Bittlingmayer, Did Antitrust Policy Cause the Great Merger Wave?, 28 J.L. \& ECoN. 77 (1985); George Bittlingmayer, Decreasing Average Cost and Competition: A New Look at the Addyston Pipe Case, 25 J.L. \& ECON. 201 (1982); Pirrong, supra note 14; Abigail McWilliams, Rethinking Horizontal Market Restrictions: In Defense of Cooperation in Empty Core Markets, 30 Q. REV. ECON. \& Bus. 3 (1990); Sjostrom, Antitrust Immunity, supra note 14; Lester G. Telser, Competition and the Core, $104 \mathrm{~J}$. POL. ECON. 85 (1996); Lester G. Telser, The Usefulness of Core Theory in Economics, $8 \mathrm{~J}$. ECON. PERSP. 151 (1994); Wiley, supra note 119.

121. Thus, William Sjostrom believes that empty cores can stem from the lack of a price on the industry supply curve for every possible quantity, which could occur because supply curves are "lumpy" or non-continuous. Where this is so, there are "gaps" on the supply curve into which the only possible equilibrium price might fall, 
lead to economic losses and potential rate wars. But, as soon as a firm removes its bloc of non-incremental capacity, remaining firms may be able to earn excess profit, again attracting entry and perhaps overcapacity. ${ }^{122}$ Certain scholars have argued as much, and there is also some empirical evidence in support of an empty core in liner shipping markets, though the evidence that exists is limited and has been criticized on methodological grounds. ${ }^{123}$

Empty core theory is problematic for several reasons, and deregulatory experience in the shipping industry suggests that, if empty cores exist anywhere, they do not exist in shipping markets. As a theoretical matter, the model requires certain problematic assumptions. First, it assumes that wherever pricing above average cost poses short term gains, an outside firm will enter, even though in an industry like liner shipping each new entry might result in longrun overcapacity requiring exit and potentially spurring rate wars. The costs of entry could drastically outweigh short-run gains. What is important to a potential entrant is not the existing market price but the market price post-entry, and if a firm can foresee that its entry would force prices below average cost, it will not enter. Next, the empty core theory assumes that additional capacity can be added only in non-incremental blocs by autonomous and self-contained firms, which can cooperate by no means except naked, multilateral restrictions on price or output. As applied to liner shipping, the argument assumes that carriers can seek entry in markets with surplus profits only by making irrevocable short term commitments

thus making the core empty. Such a situation would arguably characterize liner markets if capacity can be added only in non-incremental blocs. See Sjostrom, Collusion, supra note 15 , at 1166.

122. Suppose that a particular trade is such that when two ships service the route, the market price is above average cost, while when three ships service the route, the market price is below average cost. Suppose also that three different carriers want to serve this route. Since demand is such that only two carriers can survive in the market, one firm will always be left out. If the incumbent firms are making profit, the firm that is left out could seek to negotiate a deal with the customers of the other carriers, disrupting the original arrangement. See OECD FINAL REPORT, supra note 8, at $61-62$.

123. In particular, William Sjostrom found some empirical evidence of conference behavior arguably consistent with attempts to rationalize performance under empty core conditions. See Sjostrom, Collusion, supra note 15, at 1166. He relied, however, on a highly simplified model of liner markets and used admittedly problematic data, see $i d$. at 1162-70, and found no more than that "[t]he results [of econometric analysis], although certainly not definitive, offer further evidence for the proposition that market arrangements that appear to be cartels may be attempts to solve the problem of the empty core." Id. at 1177. Likewise, Stephen Pirrong argued energetically for the empty core hypothesis but on little more than his econometric estimation of the cost function of one liner operator and the asserted longevity and universality of the conference system. See Pirrong, supra note 14, at 107, 116-29. See generally OECD FINAL REPORT, supra note 8, at 62 (providing criticism). 
of the full capacity of their own ships. There is no reason to believe such a thing, and the argument is at odds with experience. After OSRA, the industry increased its use of vessel and space sharing as well as other non-price operational agreements that allowed carriers to rationalize capacity without naked price or output constraints. ${ }^{124}$ Thus, empty core theory ignores a solution that to the industry was made obvious by the mere pressure of competition, and it is a solution legal under antitrust laws even without the exemption. ${ }^{125}$

In any event, even if liner shipping markets had empty cores, private capacity regulation of the kind urged by the industry and its supporters-regulation by self-interested market participants themselves-would be a poor means to address the problem, because of the dramatic risk of abusive conduct lacking any pro-competitive upside. ${ }^{126}$

\section{Susceptibility to Oligopoly Conditions}

The industry also argues that unrestrained competition will lead to concentration in the industry. The argument implies that an oligopoly would be negative because it would facilitate supracompetitive prices and consolidation of control over access to ocean transport. The prediction of concentration has strong theoretical support, ${ }^{127}$ and post-OSRA practical experience bears it out.

124. See OECD FINAL REPORT, supra note 8, at 49 ("[A] growing proportion of the top 20 operators' fleets is made up of time-chartered vessels, indicating a trend away from self-ownership to relatively more flexible asset management arrangements."); id. at 57 ("Slot chartering allows carriers to respond flexibly to demand without necessarily purchasing a new vessel.").

125. The typical non-price operational agreement among carriers would not violate antitrust regulations, at least so long as it contains no direct constraints on price or output. See 13 HERBERT HOVENKAMP, ANTITRUST LAW If 2100(g) (1999); U.S. Dept. of Justice and Federal Trade Commission, Antitrust Guidelines for Collaborations Among Competitors $\$ 3.3$ (2000). Such agreements would also likely qualify for treatment under the National Cooperative Research and Production Act, 15 U.S.C. $\S 4301-05$, permitting them to avoid even the possibility of treble damages liability upon the filing of a preliminary notice with the enforcement agencies. See 15 U.S.C. $\S 4305$; 13 HOVENKAMP, supra, T $2100 \mathrm{~h}$.

126. As Professor Wiley put it, "Core quota managers will find their powers for good tempt them to evil. They must be either saintly or regulated. . . Legalizing core quotas would render useless the easy ways of outlawing cartels, because no simple, surefire test distinguishes laudable core management from injurious cartel conduct." Wiley, supra note 119, at 575-76. A better solution, in other words, would be long-term contracting directly between shippers and carriers, subject to antitrust control. Even Professor Telser thought that long-term contracting could be a solution to excess capacity where costs are lumpy or demand is uncertain. See id. at 565 (citing Lester Telser, Cooperation, Competition, and Efficiency, 28 J.L. \& ECON. 271, 274-76, 277-78, 284-85 (1985)).

127. Liner shipping is characterized by factors traditionally thought to facilitate oligopoly. Its customers are numerous and unaffiliated, and their identities change frequently. George Stigler has shown that oligopoly should be more stable where 
But the relevant policy question is not whether competition would lead to oligopoly but whether oligopoly pricing regulated by antitrust law would be worse than conference price-fixing. There are theoretical reasons to believe that capacity rationalization by oligopolists, constrained by a competitive fringe, is preferable. Conferences have an incentive to price off their least efficient member, and there is empirical evidence that they traditionally did so. ${ }^{128}$ An oligopolist, by contrast, is motivated to minimize costs by competition from other oligopolists and from fringe competitors. Therefore, competition should result in net pro-competitive consolidation, whereas conference price-fixing leads to subsidization of inefficient carriers.

\section{Does the Conference System Result in Supracompetitive Price?}

If shipping conferences are harmful, it should be chiefly because they charge inefficiently high rates. Carriers, however, point out that rates actually fell for a period of roughly twenty years (a decline that appears to have ended with recent increases in global trade volume $^{129}$ ) and cite this as evidence that they have no power over rates. ${ }^{130}$ Evaluating this claim is more difficult than it may seem because carrier cost data is difficult to secure, ${ }^{131}$ and much of the evidence of price behavior is contradictory and difficult to interpret. ${ }^{132}$ However, the evidence that exists is either inconclusive or tends to suggest that conferences had some ability to inflate price. ${ }^{133}$

cheating is more difficult to detect, and that detection should be more difficult under these circumstances. See George J. Stigler, A Theory of Oligopoly, 72 J. PoL. ECON. 44, 47 (1964). Likewise, liner markets may contain some entry barriers. See infra notes 154-59 and accompanying text. Finally, containerization and intermodalism are thought to have led to large scale economies, which also should encourage ongoing consolidation.

128. See OECD FINAL REPORT, supra note 8, at 59.

129. See Federal Maritime Commission, 43RD ANNUAL RePORT For Fiscal YEAR 2004, at 5 (2005) [hereinafter FMC, FY 2004 REPORT].

130. See id.

131. See OECD FINAL REPORT, supra note 8, at 31; Pirrong, supra note 14, at 107.

132. The data are contradictory because with some frequency prices have behaved differently in seemingly similarly situated trades, and they are difficult to interpret because of the size and complexity of the industry and the range of factors other than carrier market power that could conceivably affect rates. See OECD FINAL REPORT, supra note 8 , at 40 .

133. The evidence is in conflict as to whether there was ever a correlation between conference market share and freight rates. Compare CLYDE \& REITZES, supra note 15 (finding no correlation between market share and rates), with Fox, supra note 15 (finding such a correlation). However, a 1995 econometric study by Federal Trade Commission staff economists found that freight rates went down significantly where 
Moreover, the fact that prices have fallen over a given period is as theoretically consistent with market power as it is with lack of market power, since even monopoly maximizing rates are sensitive to changes in demand over time. ${ }^{\mathbf{1 3 4}}$ Indeed, the practical evidence is more consistent with market power because, though rates were in decline for some time, the decline began only around the time of the first U.S. deregulatory reforms in 1984, and rates have declined from a peak during the 1970s. ${ }^{135}$ This decline coincides with a steady decrease in the influence of the conferences themselves, ${ }^{136}$ and if anything it is more consistent with the idea that conferences exerted market power.

\section{E. Will Competition Lead to Inadequate Returns, Investment Uncertainty, and Lower Service Quality?}

Carriers have argued that open competition would lead to overcapacity and pricing below cost, and in support they frequently argue that their industry already performs poorly economically. However, even if liner shipping has performed comparatively poorly overall as compared to industries generally, the evidence suggests that it performs about as well as other transportation sectors. Moreover, the best-performing liner carriers perform quite well by comparison to railroads and other transport industries, and most of the top twenty carriers have been in business for over twenty yearsthat is, throughout the entire period of price competition under deregulation. ${ }^{137}$ The evidence of the past few years has indicated that leading carriers are beginning to do very well. ${ }^{138}$ Thus, while it may be that many carriers have struggled since price competition began,

carriers were permitted directly to negotiate independent service contracts. See CLYDE \& REITZES, supra note 15 , at 2.

134. As the OECD Report pointed out, even the U.S. telephone industry experienced steeply falling prices for long distance service throughout the entire period up to the break-up of AT\&T in 1980, before which AT\&T was an unchallenged monopolist. See OECD FINAL REPORT, supra note 8, at 42.

135. See id. at 40 .

136. That the influence of the conferences has declined appears now fairly well documented. The FMC has found that since OSRA the ability of conferences and discussion agreements to increase rates by way of voluntary pricing guidelines and non-binding common tariffs is dependent on demand. See FMC, OSRA REPORT, supra note 17 , at 14 .

137. See OECD FINAL REPORT, supra note 8, at 45-46.

138. International trade volume has expanded in the past few years and in terms of value reached record highs in federal fiscal year 2004. While carriers face fuel cost-related strains, rates are rising. Chief evidence of the industry's flourishing under these conditions is that carriers have expanded not just to meet the current excess demand, but much more so: global containership capacity expanded by eleven percent during federal fiscal year 2005, see FED. MAR. COMM'N, 44TH ANNUAL REPORT FOR FISCAL YEAR 2005, at 5 (2006); new ship orders currently planned will expand world capacity by fifty percent. See FMC, FY 2004 REPORT, supra note 129, at 5. 
that struggle may reflect no more than the healthy market function of forcing exit of higher-cost firms. ${ }^{139}$

In any case, it appears that the carriers may have contributed to whatever underperformance they have experienced by engaging in service competition through investment in overcapacity. As previously explained, the conference system at least sometimes may have encouraged inefficient service competition, financed through profit. There is empirical evidence to the contrary, finding no link between conference control and overcapacity, ${ }^{140}$ but the evidence is based only on the study of closed conferences. ${ }^{141}$

Carriers also argue that the lack of adequate return they anticipate under competition and the capacity instability it will cause will result in a loss of service quality. ${ }^{\mathbf{1 4 2}}$ A generalized decrease in shipping rates persisted from the enactment of the Shipping Act, with its initial liberalization of individual service contracting, until recently, but there is no evidence of an impact on service. ${ }^{143}$

\section{Why Would Harmful Conference ACTIVIty Not INVITE CHEATING AND NEW ENTRY?}

A final problem remains: if conferences are inefficient, and their collaborative work is not merely a pro-competitive effort to control otherwise unmanageable capacity, then abuses by conferences should invite cheating and new entry and should render them comparatively harmless. ${ }^{144}$ Moreover, carriers note that individual ships, by their

139. Indeed, the early deregulatory steps appearing in the Shipping Act in 1984 were taken in part because a 1982 report of the General Accounting Office found the industry to be doing much better than it claimed. See GAO REPORT, supra note 5, at 11-17; H.R. REP. 98-53(II), at 4 (1984) (House Committee Report accompanying 1984 Act, noting reliance on GAO findings).

Likewise, carriers argue that without horizontal capacity rationalization they will face unacceptable investment risk. But ocean carriers face investment risk similar to actors in other capital-intensive industries, which perform well under antitrust law.

140. See, e.g., DEAKIN \& SEWARD, supra note 37.

141. Closed conferences should be better able to rationalize capacity. While closed conferences are still theoretically permitted in some trades, they have long been illegal in U.S. shipping, and in practice even where they are permitted, they rarely exercise membership restrictions and operate essentially as open conferences. See OECD FINAL REPORT, supra note 8 , at 53.

142. See id.

143. See id. at 22, citing Federal MARITIME COMMISSION, SECTION 18 REPORT ON THE SHIPPING ACT OF 1984 (1989).

144. A basic prediction of economic theory is that in the absence of entry barriers, any abuse by a cartel of its position should create the possibility of surplus for other competitors and therefore should invite both disciplinary competition and opportunistic cheating by its own members. See FrEDERIC M. SCHERER, INDUSTRIAL 
nature, are moveable capital, ${ }^{\mathbf{1 4 5}}$ and some believe predatory retaliation against new entrants is slow. ${ }^{146}$ Carriers and some academics argue that liner conferences have historically been longlived and stable, a result that should not follow if the conferences have ever abused their position. ${ }^{\mathbf{1 4 7}}$

These claims are subject to several theoretical criticisms and are at odds with recent experience under OSRA's deregulatory innovations. Most importantly, unlike cartels operating under normal competition and subject to antitrust law, liner conferences throughout their history have had the benefit of a powerful, government-sanctioned cartel enforcer-the FMC and its predecessors. Prior to OSRA, both conference tariff rates and deviations from them were required to be on file with the FMC and available for public review, ${ }^{148}$ and between 1961 and 1999 they were enforced by the FMC as a matter of law. ${ }^{149}$ Conference members had no legal right of independent action prior to OSRA, and even where

Market Structure AND Economic Performance 171 (2d ed. 1980) (noting "the tendency for informal price-fixing and output-restricting agreements to break down").

145. Ships, obviously enough, are "moveable," and it is therefore often suggested that particular trade routes are highly contestable. See HERMAN, supra note 20, at 5; Sjostrom, Modeling Competition, supra note 14, at 2.

146. See John Davies, Impediments to Contestability in Liner Markets, 25 LOGISTICS \& TRANSP. REV. 325 (1989).

147. See, e.g., Pirrong, supra note 14, at 116; Sjostrom, Modeling Competition, supra note 14, at 2. Professor Sjostrom has gone so far as to say that the conference system is popular with shipping consumers, though his assertion seems somewhat incautious. The evidence he cites comes mainly from small shippers, see Sjostrom, Modeling Competition, supra note 14, at $2 \& \mathrm{nn} .7-8$, who would be less able to negotiate favorable rates with carriers even in competitive environments, and it is also at odds with the large body of evidence from shippers of all sizes. See ALEXANDER REPORT, supra note 38, at 304-08 (noting large volume of complaints Committee received from shippers and the broad shipper support for extensive regulation of conferences, including strong supervision of rates); see also John S. McGee, Ocean Freight Rate Conferences and the American Merchant Marine, 27 U. CHI. L. REV. 191, 231-38 (1960).

148. See sources cited infra note 152. Even under the 1984 Act, direct negotiation between shippers and conference members was limited by FMC rule. See Paul S. Edelman, The Ocean Shipping Reform Act of 1998, 9 CURRENTS 65, 65 (2000).

149. Enforcement of tariff terms, including prosecution of secret rebates and other undercutting activities, was added by the 1961 Shipping Act amendments. Such enforcement grew to become a dominant feature of the FMC's activities, perhaps because the agency was incentivized by the large penalties available in tariff enforcement, and by 1992 they constituted two-thirds of the agency's enforcement activities. See ADVISORY COMM'N REPORT, supra note 17, at 107-10. Tariff enforcement was effectively ended by OSRA, with the adoption of freely available service contracting. Cf. 46 U.S.C. app. $\$ 1709(\mathrm{~b})(2)(\mathrm{A})$ (prohibiting the charging of rates by a common carrier not contained in a filed tariff or service contract).

Enforcement of tariff rates was urged by the Alexander Committee as a means of protecting shippers, given the Committee's concern for the perceived harm of discriminatory pricing. See ADVISORY COMM'N REPORT, supra note 17, at 14. Presumably, neither the Committee nor the Congress of 1916 intended this provision as a key protection for conference market power, but that is arguably what it has been. 
such action was permitted by a particular conference, shipping law prior to OSRA required that the rate and terms of any individual service contract be filed with the Commission and available for public review. ${ }^{150}$ Thus, cheating by conference members was not only difficult and easily disciplined by conferences, it was in fact illegal. ${ }^{151}$ In short, until OSRA, the liner conferences had the one thing that most cartels lack, the lack of which makes most cartels unstable-a highly effective regime of cartel enforcement.

Prior to OSRA, the conferences also had a variety of devices at their disposal to discipline their markets and protect collectively-set rates, ${ }^{\mathbf{1 5 2}}$ and even where some restrictive devices were prohibited, as under U.S. law, ${ }^{153}$ conferences historically retained a variety of disciplinary tools. ${ }^{154}$ For example, U.S. policy has historically

150. See id. at 107-10.

151. See id.

152. For example, conferences in most trades outside of U.S. foreign commerce have always been "closed," meaning they simply restricted their own membership, see ADVISORY COMM'N REPORT, supra note 17, at 37; GAO REPORT, supra note 5, at 4, and often controlled their own capacity by limiting sailings by individual members, GAO REPORT, supra note 5, at 4 . To suppress internal price competition, conferences employed revenue pools, under which revenues earned by individual member companies serving the same ports were pooled together and periodically distributed among the member companies according to pre-approved schedules, thus eliminating the incentive for secret undercutting. See id. at 4-5. Prior to 1984 revenue pools required FMC prior approval, but since that time they have been permissible and within the antitrust exemption, so long as filed and not contrary to the standard of 46 U.S.C. app. $\S 1705(\mathrm{~g})$. As for price competition by independents, conferences seem mainly to have employed various species of loyalty contracts with shippers, such as better sailing schedules through capacity rationalization that independents could not match. See GAO REPORT, supra note 5, at 5. Finally, conferences sometimes resorted to more drastic measures, such as boycotts of shippers who used non-conference carriers and the so-called "fighting ship," a vessel subsidized by conference members that would meet or undercut the lower rates changed by any independent until it either left the trade or joined the conference. See id. Both practices have always been illegal under U.S. shipping law, as contrary to the basic "common carriage" philosophy of U.S. policy. Cf. 46 U.S.C. app. $§ 1709(\mathrm{~b})(3)$ (prohibiting retaliatory boycott); 46 U.S.C. app. $\S 1709(\mathrm{~b})(6)$ (prohibiting fighting ships).

See generally Sjostrom, Modeling Competition, supra note 14, at 1 ("At different times, subject to various regulations, [conferences] have set tariffs, employing policing agencies to check on adherence to the tariff. Members have been fined out of the membership bonds they post. . . They may also pool revenues and allocate particular ports.").

153. For example, U.S. law has long mandated "open conferences," without membership restrictions, has always prohibited "fighting ships," and has traditionally placed some limits on such devices as revenue pooling agreements and loyalty contracts. See GAO REPORT, supra note 5, at 5-9.

154. Not least important, conferences sometimes used disciplinary tools that were not permitted by law. See H.R. REP. 98-53(II), at 4-5 (1984) (describing the late 1970s U.S. prosecution of executives of North Atlantic Conference carriers for collusive conduct beyond the scope of approved agreements, resulting in multi-million dollar fines). 
permitted the use of one particular form of entry deterrence that is thought to have some substantive effect even in the absence of other entry barriers-the so-called "dual-rate" or "loyalty" contract. ${ }^{155}$ Even one of the conference system's defenders has argued that loyalty contracts can deter entry, even by lower cost entrants, so long as those entrants are capacity constrained. ${ }^{156}$ In any event, a chief characteristic of most conferences has been their well-funded, wellstaffed and influential central secretariats, a feature that has been noted nearly as long as conferences have existed. ${ }^{157}$

Moreover, despite superficial appearances there remains steady debate concerning the contestability of liner markets. In fact, there is reason to believe that substantial portions of world shipping capacity are not suitable for competition in the general cargo trades that make

155. Under a dual-rate contract, the shipper agrees to purchase exclusively from the conference and in return receives a discount. If it then purchases from a different carrier, it must pay damages. Another type of loyalty contract is known as the deferred rebate, under which if a shipper purchases exclusively from a carrier or conference for some stated period it accrues a rebate, but the rebate is returned only at the end of that stated period. If the shipper purchases from another carrier during the period, it forfeits the rebate. Though some have argued that the two arrangements have different substantive consequences, it seems more probable that in the absence of enforcement costs they are identical. See William Sjostrom, Monopoly Exclusion of Lower Cost Entry, 22 J. TRANSPORT ECON. \& POL'Y 339, 339 (1988) [hereinafter Sjostrom, Monopoly Exclusion]; McGee, supra note 147. In any event, deferred rebates were long illegal under U.S. law, while dual-rate contracts were traditionally permitted. See Sjostrom, Monopoly Exclusion, supra at 338 , as to the brief period during which dual-rate contracts were also illegal under the case of Fed. Mar. Bd. v. Insbrandtsen Co., 356 U.S. 481 (1958).

156. Professor Sjostrom argues that a component of the transportation cost faced by a shipper is the sum of the physical storage cost of inventory and the lost time value of the good while waiting unsold in storage. This cost can be lowered by paying a premium to a carrier to add greater frequency of shipment and, other things equal, a rational shipper minimizes transportation cost by paying for added frequency until the frequency premium exceeds the recouped storage cost. In short, the demand for frequency of shipping service is downward sloping. It follows that wherever the price of added frequency falls, other things equal, shippers will desire greater frequency.

Thus, the entry of a lower-cost new entrant might attract shippers. However, if the entrant is capacity constrained, it may be unable to satisfy the demand generated by any price lower than the incumbent's cost. If so, shippers would lose some surplus. Shippers may be able to earn more overall surplus by agreeing to an exclusive contract with the incumbent, under which the incumbent might charge more than the lowercost entrant's minimum price, while incumbent would provide all needed demand. Shippers will prefer such a contract if the product of the additional capacity purchased under the exclusive contract times the price at which shippers would have purchased that capacity exceeds the lost surplus suffered by purchasing from the lower-price but capacity-constrained incumbent. Professor Sjostrom posits that incumbent conferences will normally be able to satisfy excess capacity demands, whereas non-conference entrants will frequently be capacity constrained. See Sjostrom, Monopoly Exclusion, supra note 155, at 341-42; see also Jong-Say Yong, Excluding Capacity-Constrained Entrants Through Exclusive Dealing: Theory and Application to Ocean Shipping, $44 \mathrm{~J}$. INDUSTRIAL ECON. 115 (1996) (applying game theoretic model to reach similar result).

157. See, e.g., RING COMM'N REPORT, supra note 38, at 20-27. 
up most Shipping Act-covered commerce. Bulk cargo ships and some others cannot be switched into general cargo competition at low cost; ${ }^{158}$ there is at least some specialization of ships to particular routes even in general cargo trades, ${ }^{159}$ and at least some other nontrivial sunk costs may inhere in serving individual routes in general cargo trades. ${ }^{160}$ Thus, except for high value and very low value goods, the bulk of cargo transported by containerized ship cannot be costeffectively shipped by alternative means. ${ }^{161}$

In any case, the frequent suggestion that liner conferences are long-lived and stable is misleading in two respects. First, while it is true that throughout its history and up until OSRA the industry was dominated by conferences, the conferences themselves typically lasted only a few years, and individual conference membership fluctuated along with carriers' business strategies. ${ }^{162}$ Second, OSRA's first steps towards deregulation and the introduction of price competition through confidential, individual service contracts have hastened the virtual demise of the conference system in less than ten years. ${ }^{163}$ Finally, the most telling evidence may simply be that in the short period since OSRA, in which carriers have no longer been able to fix binding common tariffs, the conference system has essentially collapsed, but the industry appears to have performed well. ${ }^{164}$

158. This is so because virtually all general cargo shipping is now by container ship, and modification of other ships for container carriage would likely be prohibitively expensive. Containerships are much more expensive than ships fitted for other carriage - a containership can cost on the order of three and a half times that of a similar sized bulk carrier. See Davies, supra note 15, at 417; see also HERMAN, supra note 20 , at 6 . Thus, entry would be difficult by ships specially suited to refrigerated cargoes, those designed for bulk shipping, and so-called "roll on/roll off" ships, which are designed to handle wheeled cargo trailers, containers with chassis, and selfpropelled equipment, such as automobiles, which can be driven onto and off a vessel over ramps. See generally ADVISORY COMM'N REPORT, supra note 17, at 17 \& n.3.

159. See Sjostrom, Modeling Competition, supra note 14, at 6.

160. See CLYDE \& REITZES, supra note 15, at 22 (hypothesizing that "there my be sunk costs involved in serving a given route (i.e., costs of warehouses, cargohandling equipment, and other terminal facilities)").

161. See OECD FINAL REPORT, supra note 8, at 20 (citing MARY R. BROOKS, SEA Change in Liner Shipping: Regulation and Managerlal Decision Making in a GLOBAL INDUSTRY (2000)).

162. See OECD FINAL REPORT, supra note 8, at 62 (citing N. Shashikumar, Competition and Models of Market Structure in Liner Shipping, 15 TRANSPORT REV. 3 (1996)).

163. See supra notes 25-104 and accompanying text.

164. See id. 


\section{CONClusions: The Future OF THE ExEMPTION AND A BIT OF HISTORICAL PERSPECTIVE}

\section{A. Retention of the Antitrust Exemption}

In any event, having said all that, industry raises one last defense of its remaining exemption-that because of the rise of independent service contracting, the collaboration still permitted under OSRA must somehow be harmless. That claim is surely false. In fact, problematic behaviors persist, and arguments for any procompetitive upside, which come almost exclusively from the industry, are really the same as those made in defense of the conference system itself. ${ }^{165}$ While it is occasionally suggested that presently there is no evidence of competitive harm post-OSRA, ${ }^{166}$ such claims are false.

First, the discussion agreements and voluntary guidelines for service contracting still tolerated by OSRA routinely involve a large amount of information sharing that would likely violate U.S. antitrust laws but for the exemption. ${ }^{167}$ Despite the introduction of competition, this conduct appears to have facilitated significant collusion. Though the voluntary guidelines have proven vulnerable to independent service contracting, particularly in times of overcapacity, they facilitate generalized rate increases in times of high demand and capacity utilization, ${ }^{\mathbf{1 6 8}}$ and carriers may benefit more from rate increases in times of high demand than shippers do from rate troughs in times of low demand.169 Indeed, were generalized rate increases ineffective in the face of independent contracting, one would expect the conferences not to go to the effort and expense of doing them, and yet they do so. ${ }^{170}$ More significantly, the guidelines and discussion agreements facilitate price-fixing of the many ancillary surcharges that carriers pass on to shippers, even in independent service contracts, notwithstanding the fact that freight rates themselves remain negotiable. These charges often constitute significant

165. See Papavizas \& Kiern, supra note 4, at 488-89 (discussing industry arguments).

166. Such claims normally come from the industry itself, and when they are made by economists they normally reflect only scientific caution. See, e.g., OECD FINAL REPORT, supra note 8, at 62 (citing N. Shashikumar, Competition and Models of Market Structure in Liner Shipping, 15 TRANSPORT REV. 3 (1996)).

167. See Ocean Shipping Reform Act of 1998, supra note 3.

168. See FMC, OSRA REPORT, supra note 17, at 13-14, 28-29. Moreover, evidence that carriers can price discriminate between high and low value cargo, owing to the general inelasticity of freight rates for high value freight, suggests they should be able to constrain prices through voluntary guidelines as to high value goods even in times of slack demand. See Bryan, supra note 15; Fox, supra note 15.

169. See OECD FINAL REPORT, supra note 8, at 67.

170. See FMC, FY 2004 REPORT, supra note 129, at 6-7 (noting GRIs in a variety of U.S. trade lanes in federal fiscal year 2004). 
portions of overall transport cost and also result in major (and sometimes unseen) shifting of risk to shippers. ${ }^{171}$

Second, while OSRA has introduced price competition, independently negotiated rates are probably available only to shippers large enough to exert influence in negotiation with individual carriers. Whereas published tariff rates now largely serve as benchmark prices below which large shippers enjoy deep discounts through service contracts, small shippers typically have no choice but to accept the benchmark rate. ${ }^{172}$ Thus, as to small shippers, the conferences remain effective price fixers.

Furthermore, the operational agreements now prevalent among carriers come within OSRA's antitrust exemption, and while they appear to promise pro-competitive benefits, there is no obvious reason they should not be subject to antitrust laws. Pro-competitive aspects of inter-carrier operational agreements would never be subject to per se analysis, and even if exposure to rule-of-reason scrutiny would burden inter-carrier negotiations to some extent, there is no obvious reason such agreements should be treated differently than any other efficiency enhancing cooperative behavior. Moreover, while they appear likely to result in productive efficiencies, collaborations amongst carriers can easily shield conduct harmful to competition. ${ }^{173}$

\section{B. The Bigger Picture}

One final question remains, and that is just how the congressional action of 1916 should be understood historiographically. It seems likely that when Congress first enacted shipping legislation, it mistook the facts before it. The Alexander Committee and the Congress of 1916 believed they were dealing with a new or special industrial phenomenon ${ }^{\mathbf{1 7 4}}$ and that the economic crisis in ocean shipping reflected a general crisis in U.S. industry. Very similar

171. See OECD FINAL REPORT, supra note 8, at 43-44. These apparently collusively fixed surcharges include a variety of costs that presumably should vary as among carriers, such as equipment repositioning charges and paper work filing. Carriers have also managed to pass on a number of major variable charges to shippers (such as currency and fuel price fluctuations), so that shippers are then faced with rates that vary highly from the published tariff. Finally, the lack of transparency involved in the assessment of these charges and the fact that they are presented to shippers as non-negotiable "direct costs" suggest that surcharges are simply a continued price-fixing effort. See $i d$.

172. See id. at 66.

173. See 13 HOVENKAMP, supra note 125 , ๆ $2100 \mathrm{~b}$ ("While many joint activities are clearly anticompetitive and many others are clearly competitive, in the middle are a significant number whose effects are ambiguous, at least upon an initial look."); OECD FINAL REPORT, supra note 8, at 27 (noting problems with operational agreements on file).

174. See OECD, FINAL REPORT, supra note 8, at 27. 
patterns played out in other transport sectors in the early twentieth century; indeed, this history seems part of the major rhetorical effort that culminated in the National Industrial Recovery Act fifteen years later. ${ }^{175}$

A plausible alternative explanation might be that what was before Congress was not an irremediable crisis but a period of readjustment in shipping markets to a new long-term equilibrium, a readjustment that was cut short by congressional sanction of shipping cartels. In many sectors, that readjustment, which might otherwise have worked itself toward stable long-run equilibrium, was cut short by legislative intervention at the behest of suffering industry. ${ }^{176}$ In other words, the current ocean shipping regulatory regime may best be understood as virtually the last vestigial remnant of a very large mistake of economic theory. As a consequence of that mistake, priceconstrained regulated industries over many decades undertook substantial capital and psychological commitments to inefficient modes of operation. ${ }^{177}$ It seems that Congress misunderstood the situation because, at the time, virtually everyone misunderstood it.

This interpretation matches Congress' character: Congress, like other legislatures, has a history of action without overarching plan. Its behavior over time is well characterized as a series of reactions to emergent events and perceived crises, few of which fit into any large plan and most of which have long term consequences considered by essentially no one at the time of their enactment. ${ }^{178}$

However, cynicism is not so easily avoided as to the shipping industry's century-long effort to defend the exemption. In light of events of the past few decades, which show that the traditional explanation for the exemption was faulty, their continued arguments suggest they no longer simply believe in theory or are faced with difficult circumstances. Even to the present day they persist in stressing the economic peril of competition to avoid that final bit of deregulation they most likely will face in the coming few years. ${ }^{179}$ In all likelihood, continued exposure to competition will result in turmoil for many carriers, just as they predict, but only because the near century of U.S. shipping policy contributed to industry organization, overcapacity, and other settled expectations that were themselves inefficient.

175. See id.

176. See id.

177. See id.

178. See James Willard Hurst, Law and Social Process in UNITed States HISTORY 28-92 (1960) (arguing that American public policy is characterized by "drift rather than direction"); JoHN KINGDON, AGENDAS, ALTERnATIVES AND PUBLIC POLICIES (2d ed. 2002) (laying out theory of creation of policy "agendas").

179. See, e.g., WORLD SHIPPING COUNCIL, supra note 19. 